Prepared in cooperation with the Bureau of Reclamation

Spatial and Temporal Distribution of Radio-Tagged Lost River (Deltistes luxatus) and Shortnose (Chasmistes brevirostris) Suckers in Clear Lake Reservoir and Associated Spawning Tributaries, Northern California, 2015-17

Open-File Report 2021-1061 
Cover: Photograph from aerial telemetry survey over east lobe of Clear Lake Reservoir, California, looking west across Clear Lake straits and west lobe. Photograph by Uwe Britsch, September 23, 2016, Skinner Aviation, used with permission. 


\section{Spatial and Temporal Distribution of Radio-Tagged Lost River (Deltistes luxatus) and Shortnose (Chasmistes brevirostris) Suckers in Clear Lake Reservoir and Associated Spawning Tributaries, Northern California, 2015-17}

By Nathan V. Banet, David A. Hewitt, Amari Dolan-Caret, and Alta C. Harris

Prepared in cooperation with the Bureau of Reclamation

Open-File Report 2021-1061 


\section{U.S. Geological Survey, Reston, Virginia: 2021}

For more information on the USGS - the Federal source for science about the Earth, its natural and living resources, natural hazards, and the environment—visit https://www.usgs.gov or call 1-888-ASK-USGS.

For an overview of USGS information products, including maps, imagery, and publications, visit https://store.usgs.gov/.

Any use of trade, firm, or product names is for descriptive purposes only and does not imply endorsement by the U.S. Government.

Although this information product, for the most part, is in the public domain, it also may contain copyrighted materials as noted in the text. Permission to reproduce copyrighted items must be secured from the copyright owner.

Suggested citation:

Banet, N.V., Hewitt, D.A., Dolan-Caret, A., and Harris, A.C., 2021, Spatial and temporal distribution of radio-tagged Lost River (Deltistes luxatus) and shortnose (Chasmistes brevirostris) suckers in Clear Lake Reservoir and associated spawning tributaries, Northern California, 2015-17: U.S. Geological Survey Open-File Report 2021-1061, 37 p., https://doi.org/10.3133/ofr20211061.

ISSN 2331-1258 (online) 


\section{Contents}

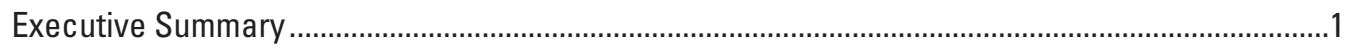

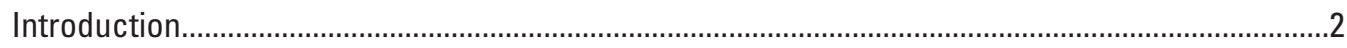

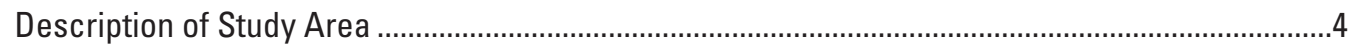

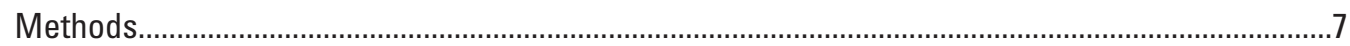

Hydrologic Conditions Influencing Movement and Migration Pathways ................................7

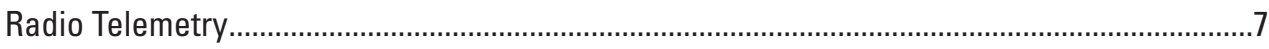

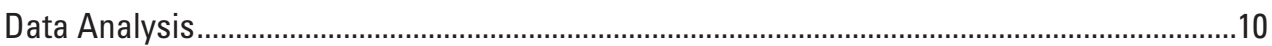

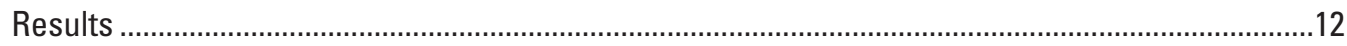

Lake Surface Elevation and Spawning Access ...................................................................12

Remote PIT Tag Detections, Discharge, and Temperature in Willow Creek ............................13

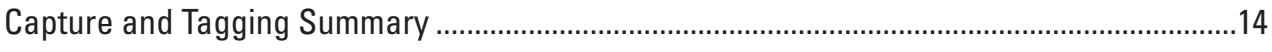

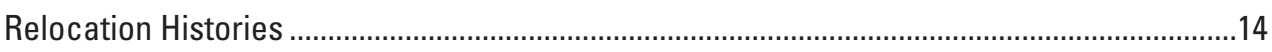

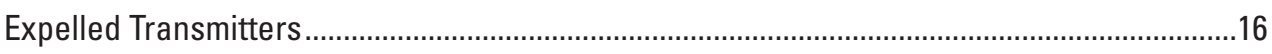

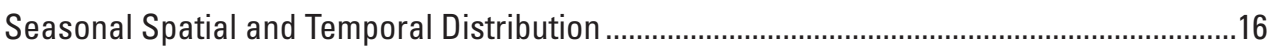

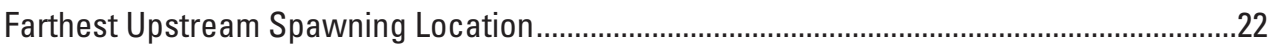

Individual Movement and Migration Tracks.....................................................................24

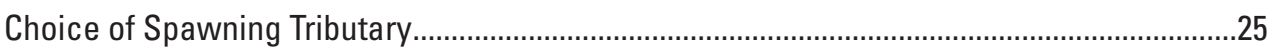

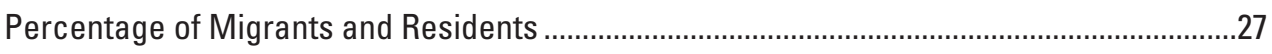

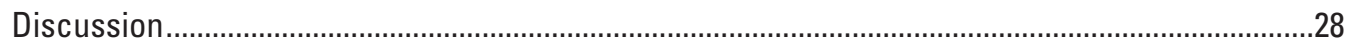

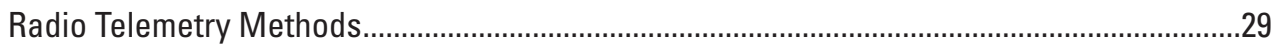

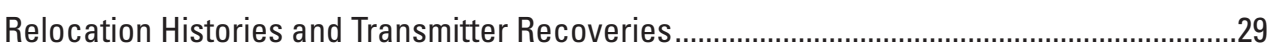

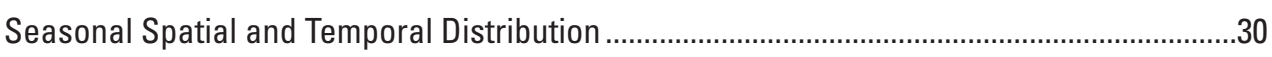

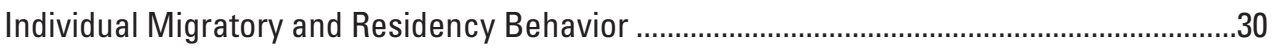

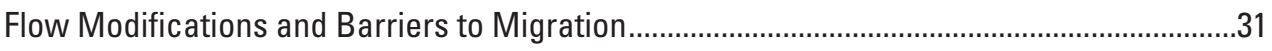

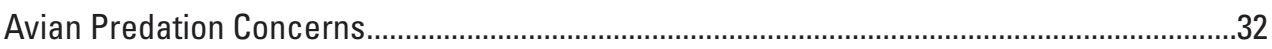

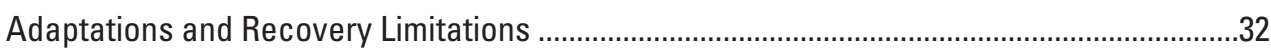

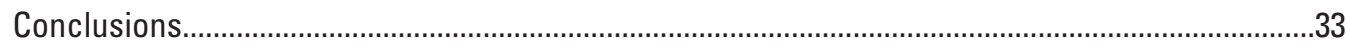

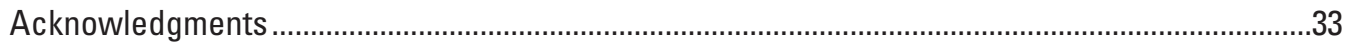

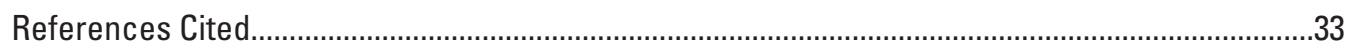

\section{Figures}

1. Map showing study area, surgery and release location, remote passive integrated transponder tag antenna arrays, Clear Lake Dam, U.S. Forest Service head gates, private dams, and spawning tributaries in the Clear Lake watershed, California.

2. Schematic diagram showing pathways and fates of adult Lost River and shortnose suckers based on observations of radio-tagged suckers in Clear Lake and its tributaries, California, 2015-17

3. Graphs showing lake surface elevations at the Dam Channel and West Lobe in Clear Lake Reservoir, California, 2015-17.

4. Graphs showing first detections of unique Lost River sucker individuals at the remote Willow Creek passive integrated transponder tag antenna array, and average discharge and average temperature at the Bureau of Reclamation Hydromet station in Willow Creek, California, 2015-17 
5. Graphs showing first detections of unique shortnose sucker individuals at the remote Willow Creek passive integrated transponder tag antenna array, and average discharge and average temperature at the Bureau of Reclamation Hydromet station in Willow Creek, California, 2015-17.

6. Graphs showing fork lengths of Lost River and shortnose suckers implanted with radio transmitters in Clear Lake, California, 2014-16. 15

7. Graph showing relocation histories of Lost River sucker females implanted with radio transmitters in Clear Lake, California, in autumn of 2014, 2015, and 2016. 17

8. Graph showing relocation histories of Lost River sucker males implanted with radio transmitters in Clear Lake, California, in autumn of 2014, 2015, and 2016. 18

9. Graph showing relocation histories of shortnose sucker females implanted with radio transmitters in Clear Lake, California, in autumn of 2014, 2015, and 2016. 19

10. Graph showing relocation histories of shortnose sucker males implanted with radio transmitters in Clear Lake, California, in autumn of 2014, 2015, and 2016. 20

11. Photographs by the U.S. Geological Survey showing a shortnose sucker male recaptured in Clear Lake, California, 6 days after surgery on October 20, 2014, with the radio transmitter, and recaptured again on October 12, 2016, with no visible signs of the radio transmitter.

12. Seasonal distribution of Lost River suckers during pre-spawning, spawning, and post-spawning periods, Clear Lake, California, 2015-17.

13. Seasonal distribution of shortnose suckers during pre-spawning, spawning, and post-spawning periods, Clear Lake, California, 2015-17.

14. Farthest upstream location of radio-tagged Lost River and shortnose suckers during spawning seasons, Clear Lake watershed, California, 2016-17.

15. Images showing individual movement and migration tracks of two radio-tagged Lost River suckers, one female and one male, by year, in Clear Lake watershed, California. Green triangles indicate first location in a given year....

16. Images showing individual movement and migration tracks of two radio-tagged shortnose suckers, one female and one male, by year, in Clear Lake watershed, California. Green triangles indicate first location in a given year...

17. Graph showing percentage of radio-tagged Lost River and shortnose suckers that were detected in Boles Creek or Upper Willow Creek, upstream from their confluence, in the Clear Lake watershed, California, during the spawning seasons of 2011, 2016, and 2017

18. Graphs showing percentage of radio-tagged Lost River and shortnose suckers that were migrants from and residents of Clear Lake, California, during the spawning seasons of 2016 and 2017

\section{Tables}

1. Date of closure and opening of two head gates, Boles Meadow and Weed Valley Reservoir, in the Clear Lake spawning tributaries during the Clear Lake radio telemetry study, California, 2015-17

2. Number of suckers captured and implanted with radio transmitters by species and sex in Clear Lake, California, in autumn of 2014, 2015, and 2016 


\section{Conversion Factors}

International System of Units to U.S. customary units

\begin{tabular}{|c|c|c|}
\hline Multiply & By & To obtain \\
\hline \multicolumn{3}{|c|}{ Length } \\
\hline centimeter $(\mathrm{cm})$ & 0.3937 & inch (in.) \\
\hline millimeter (mm) & 0.03937 & inch (in.) \\
\hline meter $(\mathrm{m})$ & 3.281 & foot $(\mathrm{ft})$ \\
\hline kilometer (km) & 0.6214 & mile (mi) \\
\hline \multicolumn{3}{|c|}{ Volume } \\
\hline milliliter (mL) & 0.03381402 & ounce $(\mathrm{oz})$ \\
\hline \multicolumn{3}{|c|}{ Concentration } \\
\hline milligram per liter $(\mathrm{mg} / \mathrm{L})$ & 0.000133526 & ounce per gallon (oz/gal) \\
\hline
\end{tabular}

U.S. customary units to International System of Units

\begin{tabular}{ccc}
\hline Multiply & By & To obtain \\
\hline \multicolumn{3}{c}{ Discharge } \\
\hline cubic foot per second $\left(\mathrm{ft}^{3} / \mathrm{s}\right)$ & 0.02832 & cubic meter per second $\left(\mathrm{m}^{3} / \mathrm{s}\right)$ \\
\hline
\end{tabular}

Temperature in degrees Celsius $\left({ }^{\circ} \mathrm{C}\right)$ may be converted to degrees Fahrenheit $\left({ }^{\circ} \mathrm{F}\right)$ as

$$
{ }^{\circ} \mathrm{F}=\left(1.8 \times{ }^{\circ} \mathrm{C}\right)+32 \text {. }
$$

\section{Supplemental Information}

Concentrations of chemical constituents in water are given in milligrams per liter (mg/L).

\section{Datum}

Vertical coordinate information is referenced to the Bureau of Reclamation Vertical Datum specific to Clear Lake Reservoir in the Upper Klamath Basin. Elevation, as used in this report, refers to distance above the vertical datum. 


\section{Abbreviations}

$\begin{array}{ll}\text { AWPE } & \text { American white pelican (Pelecanus erythrorhynchos) } \\ \mathrm{db} & \text { decibels } \\ \text { DCCO } & \text { double-crested cormorant (Phalacrocorax auritus) } \\ \mathrm{FL} & \text { fork length } \\ \text { GPS } & \text { Global Positioning System } \\ \text { LRS } & \text { Lost River sucker } \\ \text { NMFS } & \text { National Marine Fisheries Service } \\ \text { NRC } & \text { National Research Council } \\ \text { PIT } & \text { passive integrated transponder } \\ \text { Reclamation } & \text { Bureau of Reclamation } \\ \text { SNS } & \text { shortnose sucker } \\ \text { USFS } & \text { U.S. Forest Service } \\ \text { USGS } & \text { U.S. Geological Survey } \\ \text { USFWS } & \text { U.S Fish and Wildlife Service }\end{array}$




\title{
Spatial and Temporal Distribution of Radio-Tagged Lost River (Deltistes luxatus) and Shortnose (Chasmistes brevirostris) Suckers in Clear Lake Reservoir and Associated Spawning Tributaries, Northern California, 2015-17
}

\author{
By Nathan V. Banet, David A. Hewitt, Amari Dolan-Caret, and Alta C. Harris
}

\section{Executive Summary}

Data from a multi-year radio telemetry study were used to assess seasonal distribution patterns for two long-lived, federally endangered catostomids across substantially different water conditions in Clear Lake Reservoir, northern California. Lost River (Deltistes luxatus) and shortnose (Chasmistes brevirostris) suckers, two species endemic to the Klamath Basin, were implanted with radio transmitters in each of 3 years in an effort to expand our understanding of seasonal sucker movements within the reservoir and their migrations in spawning tributaries. Clear Lake Reservoir and its tributaries are part of a critical management unit within the Lost River Basin Recovery Unit for populations of Lost River and shortnose suckers. We documented residency and migratory behaviors and how behaviors were affected by lake surface elevations and water management practices.

Adult suckers were captured during autumn trammel net sampling in the west lobe of the reservoir and implanted with internal radio transmitters. A total of 163 suckers were radio-tagged (75 in 2014, 64 in 2015, and 24 in 2016); 27 more shortnose suckers were tagged than Lost River suckers to reflect the larger population of shortnose suckers in the reservoir. Sex ratios were approximately equal for each species. Aerial telemetry surveys were used to monitor radiotagged fish from January 20 to December 2 each year and to document the upstream extent of spawning migrations in the tributaries. Surveys were scheduled more frequently during the spawning season (February-June) when suckers are known to move out of the reservoir and into spawning tributaries.

To determine individual fates, relocation histories were created and grouped by species, sex, and year of release. We documented seasonal distributions during three time periods: pre-spawning, spawning, and post-spawning. Radio telemetry provided a more complete representation of seasonal distribution patterns than was available from detections of suckers with existing non-directional, remote passive integrated transponder tag antenna arrays. In years when suckers could access the spawning tributaries (2016 and 2017), we attempted to document the farthest upstream extent of migration. Poor weather conditions in spring 2017 canceled some aerial surveys during the spawning season. Individual movement and migration were variable among years, and this variation provided insights into how distribution at specific times of year may have been affected by water management.

Most radio-tagged suckers were detected from aerial surveys (94 percent). Detections were highest in the first full year after release. The most common fate was mortality from unknown causes, which accounted for approximately 45 percent of the individuals. All radio-tagged suckers remained in the reservoir in 2015, with most remaining in the larger and deeper west lobe. Mortalities from avian predation were confirmed only in 2015.

Both species were found in the east and west lobes of the reservoir during the pre-spawning and post-spawning periods in 2016 and 2017, and most radio-tagged suckers were confirmed at least once in the tributaries during spawning. Shortnose suckers were found to migrate farther than Lost River suckers and use small tributaries such as Fletcher Creek and Fourmile Creek. Shortnose suckers that migrated the farthest also were the least likely to return to the reservoir after the spawning season. We found no evidence that radio-tagged suckers that remained in the upper tributaries after spawning were able to survive and return to the reservoir. During spawning, Lost River suckers were found almost exclusively in the mainstem of Willow Creek, whereas shortnose suckers were relatively evenly distributed among Boles and Willow Creeks. Thus, Lost River suckers were absent from a large part of their designated critical habitat in Boles Creek as far upstream as Avanzino Reservoir. Shortnose suckers were found in most reaches of their designated critical habitat. Areas of critical habitat for shortnose suckers that were not surveyed for radiotagged suckers included the East Fork of Willow Creek and an unnamed tributary of Fletcher Creek to Bayley Tank. Future telemetry surveys could include these areas as well as Mowitz Creek, a separate tributary that flows into the southern end of the east lobe of the reservoir. 
In years when reservoir water surface elevations were above 1,379 meters $(4,524$ feet $)$ throughout the spawning season, most suckers performed spawning migrations (56-79 percent in 2016; 62-89 percent in 2017). For suckers monitored in both the 2016 and 2017 spawning seasons, we found evidence that some suckers remained in the reservoir even when water conditions provided access to spawning tributaries. Although it remains unclear whether radio-tagging affected migratory behavior, skipped spawning may be more common for populations in Clear Lake Reservoir compared to river-spawning populations in Upper Klamath Lake, Oregon, which migrate every year. The potential use of spawning areas within Clear Lake Reservoir during years of low water surface elevations may warrant further study.

Water control structures and small dams built for agricultural purposes in the Boles and Willow Creek watersheds may have been associated with mortalities of radio-tagged fish in 2016 and 2017. Transmitters of shortnose suckers were recovered in dry areas of Fourmile Creek upstream from such features in 2017. Similarly, shortnose suckers in upper Boles Creek had estimated mortality dates around the time that the Boles Meadow head gates were closed in late April 2016 and 2017. These results indicate that some shortnose suckers had not reached their final spawning destination prior to flow modifications in spawning tributaries. During previous work in 2011, we found direct evidence of avian predation of shortnose suckers in Boles Meadow and deposition of radio transmitters on nesting islands in the east lobe of Clear Lake Reservoir. These predation events occurred in late spring, presumably after the Boles Meadow head gates had been closed.

\section{Introduction}

The Lost River sucker (LRS; Deltistes luxatus) and shortnose sucker (SNS; Chasmistes brevirostris) are long-lived and federally endangered catostomids endemic to the Upper Klamath River Basin of northern California and southern Oregon (Scoppettone and Vinyard, 1991). Both sucker species are potamodromous, a life history strategy consisting of movements and migrations entirely within freshwater (Lucas and others, 2001; Thurow, 2016). Historically, populations of LRS and SNS were abundant throughout their range and used vast wetland and lake complexes in the Upper Klamath Basin. Spawning migrations of suckers once supported a subsistence fishery for indigenous peoples, a cannery on the Lost River near Olene, Oregon (U.S. Fish and Wildlife Service [USFWS], 2001; National Research Council [NRC], 2004), and a recreational snag fishery in the Williamson and Sprague Rivers (USFWS, 1988; Markle and Cooperman, 2002). Following the development of the Klamath Project by the Bureau of Reclamation (hereinafter, Reclamation), conversion of large amounts of wetland habitat to agricultural land, and diversion of water for irrigation, several populations and spawning subpopulations of suckers have been extirpated (NRC, 2004).
Lack of recruitment into extant spawning populations and declines in annual harvests closed the recreational fishery for suckers in 1987 (Markle and Cooperman, 2002). In 1988, both LRS and SNS were listed as endangered under the Endangered Species Act (USFWS, 1988).

Although Upper Klamath Lake, Oregon, contains larger spawning populations of LRS and SNS that have been documented for over 2 decades (Buettner and Scoppettone, 1990; Scoppettone and Vinyard, 1991; Perkins and others, 2000; Cooperman and Markle, 2003; Janney and others, 2008; Hewitt and others, 2012, 2018; Burdick and others, 2015), LRS and SNS have maintained self-sustaining populations in Clear Lake Reservoir, California (hereinafter, Clear Lake), despite being isolated from downstream habitats since the completion of the Clear Lake Dam in 1910. In Clear Lake, long-term adult sucker monitoring began in 2004 and juvenile monitoring began in 2015 (Hewitt and Hayes, 2013; Burdick and others, 2018). The recovery of LRS and SNS populations in Upper Klamath Lake is limited by high mortality of youngof-year suckers (Burdick and Martin, 2017). Whether these species, particularly SNS, are recruitment-limited in Clear Lake is less clear (Burdick and Rasmussen, 2013; Hewitt and Hayes, 2013). Sucker populations in Clear Lake are most limited by adult access to spawning habitat in Willow and Boles Creeks (Burdick and others, 2018).

A minimum lake surface elevation of 1,379 $\mathrm{m}(4,524 \mathrm{ft})$ is needed to provide spawning access to Willow Creek and its tributaries (National Marine Fisheries Service [NMFS] and USFWS, 2013; Burdick and others, 2018). Year-class strength also appears to be associated with lake surface elevation and spring inflows (Burdick and others, 2018; Hewitt and others, 2021). In 2011, 2012, and 2016, lake surface elevation exceeded 1,379 $\mathrm{m}$ during the spawning season (FebruaryMay) and was associated with moderate or abundant cohorts of young-of-year suckers (Burdick and others, 2018). The smallest year class occurred in 2012, which corresponded with lower Willow Creek inflows, minimal increases in lake elevations from January to April $(0.78 \mathrm{~m}$; Burdick and others, 2018), and fewer unique detections at the Willow Creek passive integrated transponder (PIT) tag antenna array. Larger year classes occurred in 2011 and 2016, years with high inflows, increasing lake surface elevation during the spawning season ( $>2.3-\mathrm{m}$ increase), and high numbers of unique detections in Willow Creek ( $>2,900$ in each year). Because of large interannual hydrologic variability in the Clear Lake watershed, years such as 2013 with flat or declining lake surface elevations near the 1,379-m threshold may provide very limited spawning access (Burdick and others, 2018). In these years, migrant adults and juveniles may become stranded in the upper reaches of the tributaries or attempt to find refuge in isolated pool habitats.

The timing, magnitude, and duration of spawning migrations are known to be influenced by flow and water temperature (Barry and others, 2009; Hewitt and Hayes, 2013). In years with unimpeded access to Willow Creek, migrations have begun as early as February (Perkins and Scoppettone, 
1996). The largest migrations and longest durations occur in years of moderate to high inflows from Willow Creek (Barry and others, 2009). Migrations also are associated with increasing water temperatures, beginning when temperatures are as low as 3 degrees Celsius $\left({ }^{\circ} \mathrm{C}\right)$ and stopping when temperatures reach about $12{ }^{\circ} \mathrm{C}$ (Perkins and Scoppettone, 1996; Barry and others, 2009). In contrast, migration timing of spawning suckers in the Williamson River, the primary spawning tributary for Upper Klamath Lake populations, are strongly correlated with rising water temperatures near or greater than 10 and $12{ }^{\circ} \mathrm{C}$ for LRS and SNS, respectively (Hewitt and others, 2012, 2014). Thus, LRS and SNS in the Williamson River maintain a level of reproductive isolation (Dowling and others, 2016), which is not as apparent among Clear Lake populations. Telemetry data collected in 2011 showed that most spawning LRS were detected in the lower $10 \mathrm{~km}$ of the mainstem of Willow Creek, whereas SNS were detected farther upstream and in tributaries to Willow Creek including Boles, Wildhorse, and Fourmile Creeks (U.S. Geological Survey [USGS], unpub. data, 2011). This contrasts with Upper Klamath Lake populations, where a river-spawning subpopulation of LRS was found to migrate farther upstream in the Sprague River compared to SNS that spawned in the lower Williamson River (Martin and others, 2013). During years of adequate inflows, additional years of monitoring in Clear Lake are needed to confirm species-specific differences in migration extent, distribution over multiple years, and how migrations compare to patterns observed for populations in Upper Klamath Lake. An array of remote PIT tag antennas in lower Willow Creek is important for monitoring migrations and estimating survival with capture-recapture, but cannot assess the full extent of spawning distributions for LRS and SNS.

Seasonal distribution of suckers in Clear Lake has yet to be fully investigated. Results from previous telemetry studies in Clear Lake (1994-1995 and 2010-2013) have focused primarily on the spawning season (Perkins and Scoppettone, 1996), with inconsistent monitoring during pre-spawning and post-spawning time periods (USGS, unpub. data, 2011). Skipped spawning has been proposed as a possibility in years of low flows (Hewitt and Hayes, 2013) and high flows (Perkins and Scoppettone, 1996). Suckers also could spawn in other locations where remote detection systems are not in place (Perkins and Scoppettone, 1996). The mainstem of Willow Creek has been monitored regularly during the spawning season since 2006 with remote PIT tag antennas located $3 \mathrm{~km}$ upstream from Clear Lake. However, because the antennas consist of a single array, directionality and inferences on distribution are limited. During low lake surface elevations, it has been assumed that nearly all suckers return to the west lobe of Clear Lake during the summer or autumn because of receding lake surface elevations in the east lobe (Hewitt and Hayes, 2013). Most autumn trammel net sampling also has occurred in the west lobe of Clear Lake. In 2014, a remote PIT tag antenna array was installed in the strait between the east and west lobes of Clear Lake (hereinafter, straits array). The straits array provides limited information about distribution patterns, but detections are important for capture-recapture monitoring in years when spawning migrations do not occur in Willow Creek. Because the straits array also consists of a single array that can be bypassed in years of high lake elevation, inferences on directionality are limited. In 2017, high lake surface elevations necessitated removing the straits array. Distribution patterns in Clear Lake during pre-spawning and post-spawning periods are largely based on assumptions that could be improved with a multi-year telemetry study covering the full annual cycle of adult LRS and SNS movements. Telemetry studies of LRS and SNS in Upper Klamath Lake and Lake Ewauna reported that suckers used specific refuges during periods of poor water quality in summer (Piaskowski, 2003; Banish and others, 2009). Other telemetry studies documented spawning migrations of Klamath largescale sucker (Catostomus snyderi), LRS, and SNS in the Williamson and Sprague Rivers (Ellsworth and others, 2007; Ellsworth and VanderKooi, 2011). Despite these previous studies, we lack understanding of the year-round distributions of Klamath Basin suckers, particularly in systems with highly variable water conditions.

Tributaries to Clear Lake undergo flow modifications at specific times each year depending on lake surface elevations. If lake surface elevations reach 1,381 m (4,532 ft), the U.S. Forest Service (USFS) closes head gates at Boles Meadow and Weed Valley in late spring (April-May) and opens them in October (J. Jayo, USFS, oral commun., 2018). As a result, lower sections of Willow and Boles Creeks become a series of disconnected pools in summer (Perkins and Scoppettone, 1996). A part of the North Fork of Willow Creek may serve as a summer refuge; over 62 SNS (370-420 mm) were found in pool habitats with undercut banks, rocks, willows, and algae as cover (Perkins and Scoppettone, 1996). The adaptation of SNS using in-stream pools as refuges during summer seems to be unique to SNS populations in Clear Lake and for western lake suckers in general. LRS seem to have a more typical life history of western lake suckers (Moyle, 2002). Whether closure of head gates influences the distribution, migratory behavior, residency, mortality, or susceptibility to predation has not been fully investigated.

Managers are interested in how the interannual variability of natural and anthropogenic factors influence the movements and migration of spawning LRS and SNS in Clear Lake. Understanding movements and migrations is fundamental to the behavioral ecology of populations and individuals of these potamodromous species. To avoid ambiguity in terminology that has hindered previous movement and migration studies (Dingle and Drake, 2007), we define movement and migration separately. Movement is an act of changing locations or positions over relatively small spatial and temporal scales (for example, feeding or seeking refuge; Thurow, 2016). This contrasts with migration, a more specialized type of movement that often occurs over larger spatial and temporal scales (Thurow, 2016). Dingle and Drake (2007, p. 114) define migration as 
"four different but overlapping concepts: (1) a type of locomotory activity that is notably persistent, undistracted, and straightened out; (2) a relocation of the animal that is on a much greater scale, and involves movement of much longer duration, than those arising in its normal daily activities; (3) a seasonal to-and-fro movement of populations between regions where conditions are alternately favorable or unfavorable (including one region in which breeding occurs); and (4) movements leading to redistribution or dispersal within a spatially extended population."

The aforementioned concepts apply to the potamodromous life history of LRS and SNS. Concepts 1 and 2 relate to individuals, whereas concepts 3 and 4 relate to populations. The sum of all movements and migrations during an individual's lifetime has been termed a "lifetime track," consisting of a time series of successive locations. Radio telemetry studies can monitor a part of an individual's lifetime track that can be influenced by the ability to migrate, geographic range, and habitat (Thurow, 2016), all of which are important to managers of LRS and SNS in the Clear Lake watershed. There also can be variation in the forms of migration. Although migratory fish often have been classified as obligate or facultative migrants (Dingle and Drake, 2007), whether these classifications apply to LRS and SNS in Clear Lake has yet to be fully investigated.

In collaboration with Reclamation, the USGS conducted a multi-year radio telemetry study to assess the movements and migrations of LRS and SNS in Clear Lake and its tributaries beginning in autumn 2014 and concluding in spring 2018. Monitoring of distributions was limited to January 20-December 2 each year, when suckers were predicted to be most active during the pre-spawning, spawning, and post-spawning periods. This was an effort to expand our understanding of distribution in Clear Lake and its tributaries beyond what can be inferred by non-directional, stationary detection systems. Remote PIT tag antenna arrays provided supporting data on the movements of radio-tagged suckers and timing of spawning migrations in Willow Creek. Because annual water availability in the Clear Lake watershed can vary substantially, this study was intended to document movements and migrations that span over a period that would include both wet and dry years. We summarize findings for endangered suckers in Clear Lake from radio telemetry surveys over three consecutive years to address four objectives:

1. Construct relocation histories of radio-tagged individuals,

2. Describe seasonal distributions in three variable water years,

3. Determine the upstream extent of spawning migrations and preference in the choice of spawning tributaries, and

4. Calculate the percentage of migrants and residents.
We also discuss how observed movements and migrations within spawning tributaries may be influenced by the operation of water control structures and earthen dams in Modoc National Forest. This telemetry dataset also will be useful to examine whether distribution patterns for suckers in Clear Lake are unique and contribute to the recovery actions on spawning populations for endangered suckers in their critical habitat.

\section{Description of Study Area}

Historically, Clear Lake was a natural lake in the arid high desert that included fringing wetlands and meadows. The Lost River begins at the outlet of Clear Lake and once flowed seasonally from November through May west to Tule Lake, providing spawning habitat for suckers (NRC, 2004). The completion of the Clear Lake Dam in 1910 reduced flows of the Lost River into the reclaimed wetlands of Tule Lake, provided additional water storage, and eliminated connectivity to downstream habitats (USFWS, 2001; Burdick and Rasmussen, 2013). In 1911, Clear Lake National Wildlife Refuge was established and managed by the USFWS. The lower watershed, which includes the Lost River downstream from Gerber Reservoir and Clear Lake, remains severely affected by the Klamath Project and is not suitable for suckers (NRC, 2004). Clear Lake comprises a deeper west lobe (4 m depth at full pool) and a shallower east lobe ( $2 \mathrm{~m}$ depth at full pool). The differences in depth are attributed to the inundated former marsh on the eastern side of the lake and deeper historical lake on the western side that resembles much of its former state. The two lobes are connected by a wide shallow channel and become functionally separate at lake surface elevations of about $1,378.6 \mathrm{~m}(4,523 \mathrm{ft})$. The east lobe can become completely dry when lake surface elevations decline to the proposed action minimum surface elevation of 1,377.9 $\mathrm{m}(4,520.6 \mathrm{ft})$, except for the deep pool near the dam (NMFS and USFWS, 2013). Access from the east lobe to upstream spawning tributaries is impeded at lake surface elevations of around $1,379 \mathrm{~m}(4,524 \mathrm{ft})$.

Clear Lake, Willow and Boles Creeks, and select tributaries are part of a critical management unit within the Lost River Basin Recovery Unit for LRS and SNS (NMFS and USFWS, 2013; fig. 1). Willow and Boles Creeks are the two primary tributaries for spawning populations of LRS and SNS. For LRS, critical habitat has been designated for Willow Creek (downstream from the confluence with Boles Creek) and Boles Creek upstream to Avanzino Reservoir (USFWS, 2012). For SNS, critical habitat has been designated for Willow Creek and its tributaries (Fourmile Creek, Wildhorse Creek, North Fork Willow Creek, and East Fork of Willow Creek in Oregon) in addition to Boles Creek and its tributaries (Boles Meadow, Fletcher Creek, Avanzino Reservoir, Willow Creek [different stream compared to previously mentioned Willow Creek; fig. 1], and an unnamed tributary to Fletcher Creek as far upstream as Bayley Tank). 


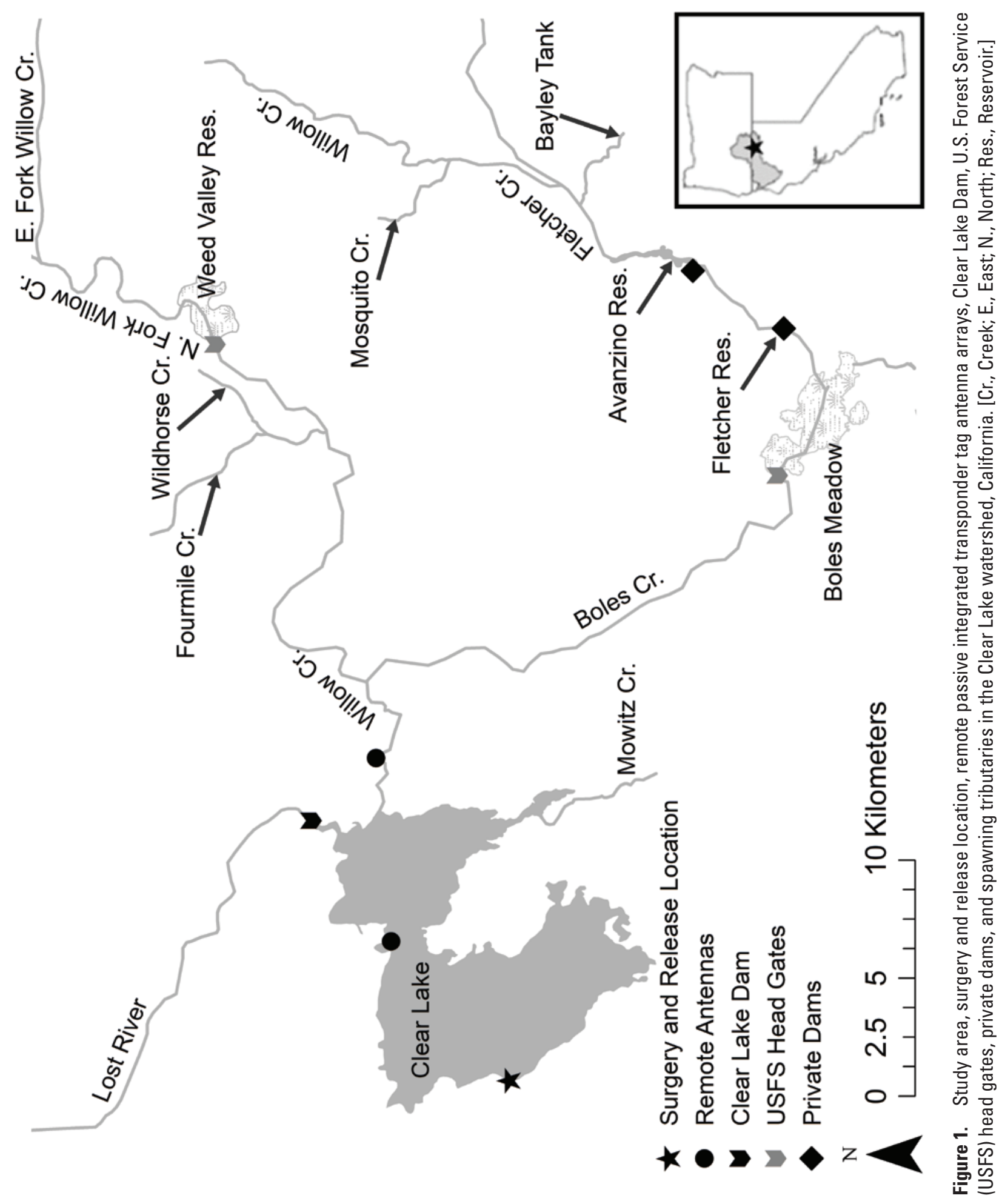


Table 1. Date of closure and opening of two head gates, Boles Meadow and Weed Valley Reservoir (fig. 1), in the Clear Lake spawning tributaries during the Clear Lake radio telemetry study, California, 2015-17.

[Symbol: -, Date of closure in 2017 unknown]

\begin{tabular}{ccccc}
\hline \multirow{2}{*}{ Year } & \multicolumn{2}{c}{ Boles Meadow head gates } & \multicolumn{2}{c}{$\begin{array}{c}\text { Weed Valley Reservoir } \\
\text { head gates }\end{array}$} \\
\cline { 2 - 5 } & Date closed & Date opened & Date closed & Date opened \\
\hline 2015 & $04-15-15$ & $10-13-15$ & $04-15-15$ & $10-02-15$ \\
2016 & $04-15-16$ & $10-13-16$ & $05-11-16$ & $10-14-16$ \\
2017 & $04-17-17$ & $10-16-17$ & - & $10-18-17$ \\
\hline
\end{tabular}

Clear Lake is within Clear Lake National Wildlife Refuge, and the upper watershed, including spawning tributaries, is located almost entirely within the Modoc and Fremont National Forests. Willow Creek, a perennial stream, is the primary spawning tributary and site of a remote PIT tag antenna array $3 \mathrm{~km}$ upstream from Clear Lake since 2006. There are approximately 11 small reservoirs within the Willow Creek drainage. The Wildhorse drainage flows into Willow Creek approximately $20 \mathrm{~km}$ upstream from Clear Lake and consists of two intermittent streams (Fourmile and Wildhorse Creeks) that provide suitable spawning habitat in high water years. The upper headwaters of Willow Creek include Weed Valley Reservoir, which is approximately $33 \mathrm{~km}$ from Clear Lake. Weed Valley Reservoir is formed by an earthen dam with head gates at the outlet operated by the USFS Devil's Garden Ranger District (Modoc National Forest). Boles Creek, an intermittent stream, is another spawning tributary that joins Willow Creek less than $8 \mathrm{~km}$ upstream from Clear Lake. The upper headwaters of Boles Creek include Boles Meadow, approximately $35 \mathrm{~km}$ upstream from Clear Lake, which consists of a flow-through, emergent wetland until the head gates at the outlet. Boles Meadow was once under private ownership when a pair of parallel canals were dug to expedite water delivery downstream and reclaim the land for agriculture (J. Jayo, USFS, oral commun., 2018). There are two privately owned and operated dams upstream from Boles Meadow that create small reservoirs for irrigation and stock (Avanzino and Fletcher Reservoirs). The specific details on the operation of these dams is unknown, although they are under the discretion of the private landowner (J. Jayo, USFS, oral commun., 2018). There also are numerous small earthen dams, approximately 22 , that are distributed throughout the Boles Creek drainage.
These dams and those in the Willow Creek drainage create ponds for stock animals throughout Modoc National Forest, although whether these dams serve as migration barriers to suckers needs further study (Burdick and Rasmussen, 2013). Mowitz Creek is another small, intermittent stream that enters Clear Lake at the southern end of the east lobe; no spawning has been documented in Mowitz Creek (Burdick and Rasmussen, 2013).

Head gates at Boles Meadow and Weed Valley Reservoir (fig. 1) are operated by the USFS Devil's Garden Ranger District. There are two time periods for operating these structures in regard to lake elevation in Clear Lake: (1) October 1April 1 and (2) April 1-October 1. If lake surface elevation on October 1 is at or above 4,532 ft, the Weed Valley and Boles Meadow head gates are operated at the discretion of Modoc National Forest (Reclamation and USFS, 1984; Reclamation, 2008). If surface elevation is below $4,532 \mathrm{ft}$, head gates must remain open from October 1 to April 1. From April 1 to October 1, the Weed Valley head gate will be opened to allow passage of water equal to the inflow from the North Fork of Willow Creek (Reclamation, 2008). Similarly, from April 1 to October 1, the Boles Meadow head gate will be opened to allow passage of water equal to the combined inflow from Fletcher Creek to the north and Fairchild Swamp to the south (Reclamation and USFS, 1984). If from May 1 to October 1, the flow in Boles Creek and the flow in North Fork of Willow Creek ceases, the operation of both head gates will be at the discretion of the Modoc National Forest (Reclamation and USFS, 1984; Reclamation, 2008). Actual dates of closure and opening of head gates during 2015-17 are presented in table 1 (J. Jayo, USFS, oral commun., 2019). 


\section{Methods}

\section{Hydrologic Conditions Influencing Movement and Migration Pathways}

This study was designed to examine the movements and migrations of spawning LRS and SNS in Clear Lake and its upstream tributaries. Radio-tagged suckers were predicted to encounter interannual variation in lake surface elevation and inflows from spawning tributaries. Additionally, we predicted that the operation of two specific head gates (Boles Meadow and Weed Valley Reservoir; fig. 1) would influence movement and migration for adult suckers. Understanding the interaction of natural and human-influenced variables in water availability provides context for the various pathways and fates of LRS and SNS in Clear Lake and its tributaries. We provide a schematic diagram of how adult suckers could navigate in Clear Lake and its tributaries in the context of lake surface elevation, Willow Creek inflows, and operation of two head gates operated by the USFS (fig. 2). Lake surface elevation below $1,379 \mathrm{~m}(4,524 \mathrm{ft})$ may prevent suckers from spawning by not providing access to spawning tributaries. In other situations, adult suckers may have access to spawning tributaries and spawn but may be impeded in their return to Clear Lake by the closure of head gates. The possible scenarios depicted (fig. 2) may not be representative of all situations or all years.

Lake surface elevation and spawning access. We summarized lake surface elevation for Clear Lake to provide context for interannual water availability over 3 years, 2015-17. Data were acquired from Reclamation (https://www.usbr.gov/ pn/hydromet/klamath/arcread.html). Two Hydromet stations were selected for Clear Lake: (1) LRS (Reclamation identifier for Clear Lake Dam Channel) and (2) CLK (Reclamation identifier for Clear Lake West Lobe). For both stations, the "FD" parameter was selected for the daily mean of all instantaneous readings across all years. Because the primary limiting factor for LRS and SNS populations in Clear Lake is access to spawning habitat during the spawning season (Burdick and others, 2018), we also plotted the approximate lake elevation when spawning access from the east lobe was impeded at $1,379 \mathrm{~m}(4,524 \mathrm{ft})$. All surface elevations are referenced to the Reclamation vertical datum specific to Clear Lake Reservoir in the Upper Klamath Basin. Figures for lake surface elevation were constructed in RStudio Version 1.3.959 using ggplot2 (Wickham, 2016).

Remote PIT tag detections, discharge, and temperature in Willow Creek. PIT tag detections in Willow Creek (2015-17) supplemented data acquired by radio telemetry and provided context on access to spawning tributaries. We summarized first detections of PIT-tagged LRS and SNS at the remote PIT tag antenna array in Willow Creek along with discharge and temperature in Willow Creek. Discharge and temperature data were acquired from Reclamation (https://www .usbr.gov/pn/hydromet/klamath/arcread.html). The Hydromet station was "WILC-Willow Creek, CA." The "QD" parameter was selected for average stream discharge (in cubic feet per second). The "WY" parameter was selected for average water temperature (in degrees Celsius). Figures for LRS and SNS remote detections in Willow Creek for discharge and water temperature were constructed in RStudio Version 1.3.959 using ggplot2 (Wickham, 2016).

\section{Radio Telemetry}

Fish collection, radio transmitters, and surgical procedures. A total of 68 LRS and 95 SNS were collected with trammel nets in the west lobe of Clear Lake and implanted with radio transmitters during the autumns of 2014, 2015, and 2016. Following capture, fish were held in live wells with recirculating lake water. During processing, if a fish was a new capture, we determined species, sex, spawning condition, and fork length (FL), and then implanted a 134.2-kilohertz full-duplex PIT tag from Biomark (Boise, Idaho). Species and sex were determined based on morphological characteristics that are described in Markle and others (2005). Fish held for radio transmitter implantation were then transferred to net pens offshore of the surgery site. Fish were captured on October 14 and 15 in 2014, October 6 in 2015, and October 19 in 2016. Fish captured on October 14, 2014, were held in net pens overnight and tagged on October 15 along with the fish captured on that day. Fish in 2015 and 2016 were captured, tagged, and released on the same day. Tagging coincided with annual autumn trammel net sampling, with additional details presented in Hewitt and Hayes (2013) and Hewitt and others (2021). Previous studies recommended implanting transmitters when water temperatures were cool because of slower metabolic rates and reduced risk of infection (Martin and others 1995; Walsh and others, 2000).

We used PISCES internal implant radio transmitters (TX-PSC-I-450 Pisces Internal Transmitter $450 \mathrm{mAh}$ ) from Sigma Eight Inc. (Newmarket, Ontario, Canada). The cylindrical transmitters measured 40 by $12 \mathrm{~mm}$ and weighed $8 \mathrm{~g}$. Five separate frequencies were used across the three release groups of transmitters $(164.230,164.290,164.330,164.340$, and 164.480 megahertz). Transmitters were coded for individual identification using the 2000 code-set, and the aggregate pulse width was 20 milliseconds (ms; $8444 \mathrm{~ms}$ ). Approximately one-half of the tags transmitted at 5-second intervals and the other half transmitted at 5.5-second intervals. Bursts were randomly offset by the aggregate pulse width to further help separate transmitters on the same frequency in the same area. Transmitters were programmed to operate in two modes in order to be active for approximately 2.5 years. One mode was programmed to deactivate the transmitter from December 2 until January 20 each year (50 days) when fish were predicted to show minimal movement in the winter. No aerial survey flights were scheduled during this time. The other mode was programmed to activate the transmitter from January 21 until December 1 each year when survey flights were scheduled. All transmitters were inspected and then tested for range and 


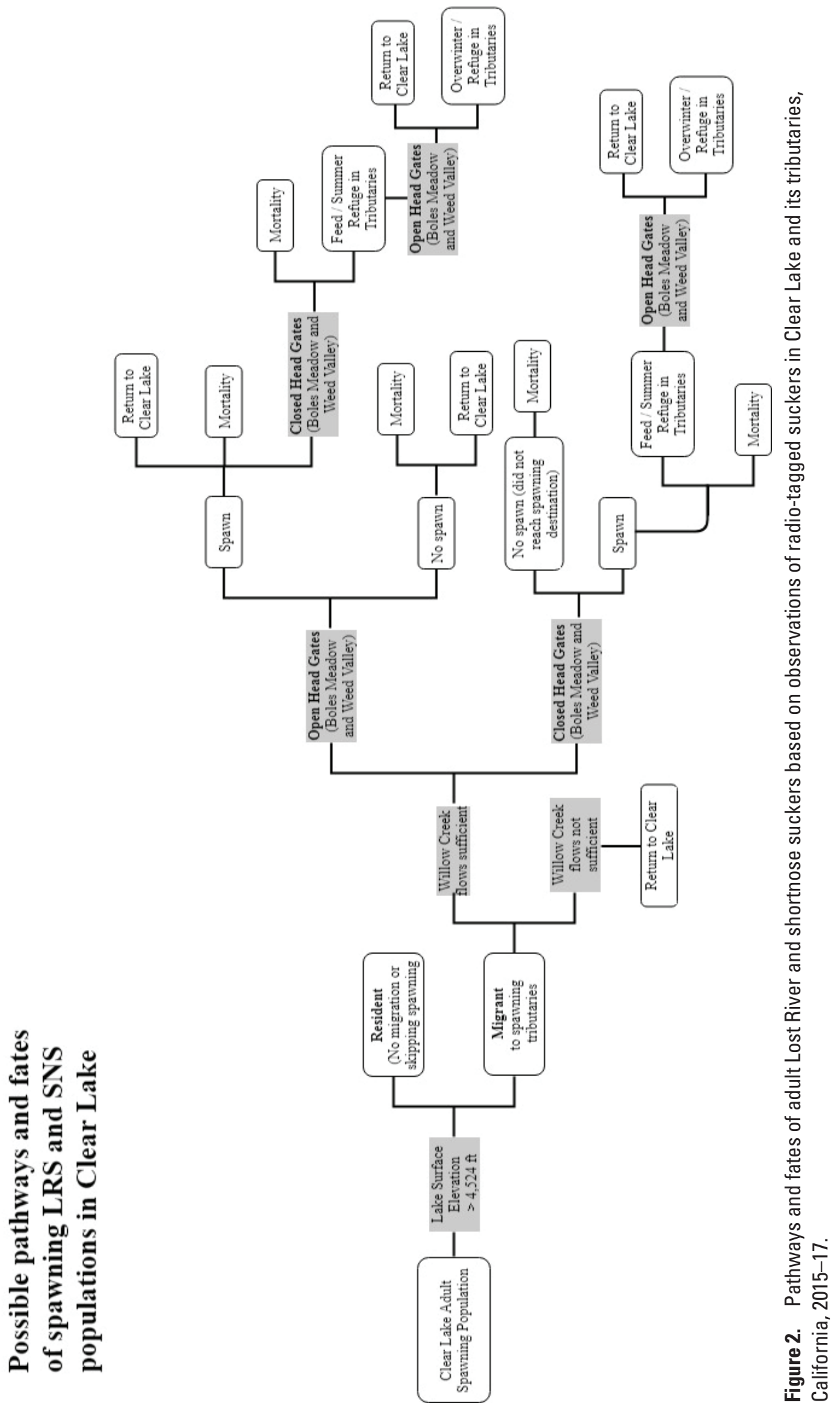


power outdoors using the same equipment that was used for aerial surveys. Only transmitters in excellent condition with performance that matched manufacturing and programming specifications were deployed. A minimum FL of $280 \mathrm{~mm}$ was required to be within the maximum allowable tag weight to body weight ratio of 5 percent. All fish selected for radiotagging were adult suckers with FL ranging from 308 to $469 \mathrm{~mm}$ for SNS and from 468 to $666 \mathrm{~mm}$ for LRS.

We followed the USGS standard operation procedure for implanting transmitters in juvenile salmonids (Liedtke and others, 2012) and modified procedures for adult suckers. One tagger was used throughout the study to minimize tagger effects. An anesthesia bath was set up and dissolved oxygen was maintained at $80-130$ percent saturation. Water temperature in the anesthesia bath was monitored to ensure that the difference in temperature between the lake water and the container water was $2{ }^{\circ} \mathrm{C}$ or less. We used tricaine methanesulfonate $\left(\mathrm{MS}-222^{\circledR}\right)$ as an anesthetic in a concentration of $40 \mathrm{mg} / \mathrm{L}$. Several post-tagging recovery containers were set up with dissolved oxygen maintained at 150-180 percent saturation. Tags were activated, disinfected in chlorhexidine solution for 15 minutes, and rinsed in distilled water. Surgical instruments included needle drivers, forceps (tissue and smooth, blunt-tip), scalpel handle and blades (number 11 straight, angled blade), sutures (size 3-0 Vicryl Plus) with a cutting needle, and catheters (size: 14 gauge by $140 \mathrm{~mm}$ [51/2 inches], shielded needle). Surgical instruments were disinfected using a chlorhexidine solution before being used again.

Following surgical station set-up, each fish was transferred to the anesthesia bath with a minimum exposure time to air, not to exceed 5-10 seconds, and its PIT tag code was recorded. The anesthesia induction time was based on when each individual fish lost equilibrium, and the fish was then kept in the bath for an additional 30 seconds. Fish were rejected for tagging if loss of equilibrium took less than 2 minutes or greater than 5 minutes. Following anesthesia, fish were immediately transferred to a V-shaped tagging platform, ventral-side up, with closed-cell foam that was pre-conditioned with 1-2 mL of diluted stress coat. Tagging stations were equipped with a flow-through irrigation system to deliver a sedation dose of anesthetic across the gills of the fish on the surgical platform. Following procedures described in Liedtke and others (2012), a 2-cm incision was made in front of the pelvic girdle to penetrate the body wall. Care was given to not puncture the hepatopancreas, which is positioned immediately against the body wall. A scalpel handle was used to push organs downward away from the body wall prior to making an antenna exit site. We used a modified shielded needle technique (Ross and Kleiner, 1982) with a plastic catheter positioned over the point of the needle as it was guided through the abdominal cavity (Liedtke and others,
2012). The exit site was located (1) one-third of the length of the pelvic fins from the base of the fins on the longitudinal axis and (2) approximately 30-50 percent of the distance from the mid-ventral line to the lateral line on the vertical axis. The antenna was routed through the catheter sheath. The tag was then inserted into the body cavity anterior end and positioned to lie directly under the incision. Three interrupted stitches were used to close the incision. Fish were then transferred to a recovery container where they were allowed sufficient time to regain equilibrium before release (approximately 15-20 minutes).

Fish tracking and data collection. Transmitter locations were collected from aerial surveys and were supplemented with PIT tag detections from two fixed antenna arrays, one in Clear Lake and the other in Willow Creek. An Orion broadband receiver/data logger from Sigma Eight Inc. was used to receive Very High Frequency (VHF) radio signals. Data were recorded on a $\mathrm{MMC} / \mathrm{SD}$ card and uploaded using the OrionTool software. A survey path specific to Clear Lake and its tributaries was created prior to this study and was used on all aerial survey flights. A track file was created for each flight using a Garmin (Garmin, Olathe, Kansas) Global Positioning System (GPS) to identify locations of transmitters and the realized flight path of each survey. When a transmitter was detected on a flight, the time on the Orion was recorded. The Garmin was synced to the same time as the Orion software, and both times were used to identify GPS coordinates for transmitters.

Location, timestamp, and signal strength for all detections recorded during a survey were uploaded and viewed with a custom Python-based mapping tool created by A.C. Harris to aid in distinguishing between noise and real contacts. Some transmitters had multiple contacts and the one with the highest power typically was selected. The noise floor for each survey was set at a power equal to -98 decibels (db). Most detections at the noise floor were deemed to be noise, with a few exceptions. Low power contacts were selected as real contacts under two conditions: (1) there was a history of detections for a given fish in the same location from other surveys and (2) the location fit within an individual's movement or migration track between prior and subsequent surveys. Some transmitters were consistently recorded at lower power. The strongest contacts were in the power range of $-60 \mathrm{db}$. Prior to flights, test beacons were set up at the USGS office and the Klamath Falls Airport as control transmitters to evaluate equipment performance on the day of the survey. Surveys by boat, vehicle, and on foot also were conducted in recovery efforts for transmitters that were assumed to be stationary. These surveys were conducted using a Lotek SRX_400 receiver (Newmarket, Ontario) and a hand-held 4-element Yagi antenna. 


\section{Data Analysis}

Capture and tagging summary. We compiled a summary table for all radio-tagged suckers by year, species and sex. Fork length histograms across all years were plotted for each species in RStudio Version 1.3.959 using ggplot2 (Wickham, 2016).

Relocation histories and fates of radio-tagged fish. We compiled relocation histories for all radio-tagged individuals from the aerial surveys over Clear Lake and its tributaries. We first classified fish as either detected or missed during each survey and later assigned confirmed or assumed final fates for radio-tagged fish. For detections other than those determined to be spurious records from noise, there were two possible explanations: (1) the transmitter was confirmed to move between different locations and the fish was assumed to be alive or (2) the transmitter was detected at the same location for at least three surveys and the fish was assumed to be dead or the transmitter had been expelled from the fish. There were four possible explanations for a transmitter that was missed during a survey: (1) the transmitter was present in the area surveyed but the signal was missed, (2) the transmitter was active but outside the area surveyed, (3) the transmitter malfunctioned following release or the battery failed, and (4) the fish and transmitter were consumed by a predator and the transmitter was deposited outside the survey area. Harvest was not an explanation for a missed detection because Clear Lake National Wildlife Refuge is closed to public access except for limited hunting opportunities.

If a transmitter was determined to still be active at the conclusion of the study, it was assigned a final fate of being either detected or missed on the final survey. There were six additional fates for radio-tagged fish that were determined based on relocation histories and assumptions or confirmations that could be inferred from these histories: (1) never detected, (2) avian mortality, (3) other mortality, (4) probable expulsion, (5) probable dead transmitter, and (6) unknown. Transmitters that were never detected had no confirmed detections and possibly failed following surgery and release. Another possibility is that the radio-tagged fish was depredated soon after release and the transmitter was deposited outside the survey area. Avian mortalities were confirmed if the radio tag was detected on breeding or loafing areas of colonial, piscivorous waterbirds during aerial surveys and later recovered. Once nesting waterbirds had left the area in autumn, targeted telemetry surveys were conducted by foot on islands to recover transmitters thought to be deposited by avian piscivores. Other mortalities were assumed if a fish was detected in the same location for at least three consecutive surveys. These mortalities were assumed to either be from natural causes or complications associated with surgery. There was the possibility that a fish expelled its transmitter following release. For example, a transmitter assigned to a fish could be detected in the same location over at least three surveys during the same time period when the PIT tag implanted in the same fish was detected on a PIT tag antenna array at a different location.
Data collection methods in autumn trammel net sampling were designed to identify recaptured radio-tagged fish and photograph the fish, specifically the incision site. This was an effort to investigate the healing of the incision and the possibility that a fish may have expelled its transmitter. Photographs of a radio-tagged fish that was recaptured following surgery are provided in this report. There also was the possibility of a transmitter battery expiring over the course of the survey period. For example, the battery in a transmitter was assumed to have expired if the transmitter was detected throughout its 2.5-year life expectancy, including three spawning seasons, and then was not detected on surveys in late spring. This was only possible for transmitters deployed in autumn 2014. The unknown fate was designated for individuals that were detected until a certain survey date, but not after, and had no indication of mortality. Unknown fates also could be a mortality that was not confirmed or a possible transmitter failure. Figures for relocation histories were constructed in RStudio Version 1.3.959 using ggplot2 (Wickham, 2016) and expanded upon the example relocation histories provided in Hightower and others (2001) for radio-tagged striped bass (Morone saxatilis).

Seasonal distribution. We evaluated seasonal distributions of radio-tagged LRS and SNS to document prespawning, spawning, and post-spawning spatial distributions in the Clear Lake watershed during three variable water years. One figure summarized each seasonal distribution by species and year. For purposes of this analysis, we defined each time period separately for each species based on PIT tag detections at the remote Willow Creek antenna array. Pre-spawning was defined from the first of the year to the initial peak in remote detections at the Willow Creek array. Spawning was defined from the first initial peak in remote detections at the Willow Creek array to the last peak in remote detections at the Willow Creek array. Peaks in remote detections at the Willow Creek array did not necessarily coincide with migrations of radiotagged fish or surveys. The summary for spawning distribution also includes locations of individuals that remained in Clear Lake and were not observed migrating in tributaries. Postspawning was defined from the last peak in remote detections at the Willow Creek array during spawning to the end of the year.

We used satellite imagery from Landsat 8 and Sentinel $2 \mathrm{~A}$ as a base map to compare seasonal distributions among individuals in variable water years and seasons by species and sex. Images were downloaded through a web portal in ArcGIS $^{\text {TM }}$ Pro 2.2 (Esri, Redlands, California) and processed to create composite images using the near-infrared, red, and green bands. The resulting false color image accentuated water levels in Clear Lake and water availability throughout the Clear Lake watershed to contrast with terrestrial landforms. In 2015, we used images from February 17, April 22, and September 29 for the pre-spawning, spawning, and postspawning periods, respectively. In 2016, we used images from February 20, April 9, and August 23 for the pre-spawning, spawning, and post-spawning periods, respectively. In 2017, 
we used images from January 5, March 10, and September 2 for the pre-spawning, spawning, and post-spawning periods, respectively. We selected imagery from these dates to provide the most cloud-free image for each time period. Locations of radio-tagged fish in seasonal distribution figures do not necessarily coincide exactly with dates of satellite images.

Farthest upstream spawning location. We assigned the farthest upstream location of radio-tagged LRS and SNS during the spawning seasons of 2016 and 2017 as the migration terminus of individual suckers. Because of low water levels during spring 2015, a spawning migration was not observed. Only radio-tagged individuals that migrated in spawning tributaries (Boles, Fourmile, Wildhorse, and Willow Creeks) were included in this analysis; fish that did not migrate out of Clear Lake during spawning were excluded. Although some individuals had multiple PIT tag and telemetry detections in the tributaries in 2016 and 2017, only the farthest upstream location was used. This was meant to identify the extent of critical habitat used by each species. The most upstream location among individuals was mapped in ArcMap ${ }^{\mathrm{TM}} 10.6$ (Esri, Redlands, California) using imagery from Landsat 8 . For this report, Willow Creek was divided into two main sections. Lower Willow Creek was defined from Clear Lake upstream to the confluence of Willow and Boles Creeks. This section included the Willow Creek PIT tag antenna array. Upper Willow Creek was defined from the confluence of Willow and Boles Creeks upstream to the headwaters.

The most upstream locations of all individuals also were used to show spatial distribution among species and sex during spawning. During the spawning seasons of 2016 and 2017, we also assessed whether individuals that migrated into small tributaries or upstream from dams or water control structures were compromised in their ability to return to Clear Lake. For example, Fourmile Creek is a tributary to Upper Willow Creek approximately $26 \mathrm{~km}$ upstream from Clear Lake that was used by two radio-tagged SNS in a 2011 telemetry study. Only one of these fish returned to Clear Lake. After spawning, we noted which individuals did not return to Clear Lake in relation to their farthest upstream spawning location, and estimated their mortality date if detected in the same location over multiple telemetry surveys.

Individual movement and migration tracks. We selected a representative subset of radio-tagged individuals to investigate annual movement and migration tracks between years. Individual patterns in movement and migration may be unique from population-level patterns. We selected one male and female of each species and plotted each individual's track over time using the program AquaTracker (Reyes-Tomassini and others, 2016). Individuals that remained in Clear Lake during the spawning season were defined as residents for that year. Individuals that moved out of Clear Lake during the spawning season were defined as migrants for that year. We provide one example each for an LRS and SNS that showed residency behavior one year and migratory behavior in another year. If migrants did not return to Clear Lake, we estimated their window of mortality and compared it to when head gates were closed each spring in Weed Valley and Boles Meadow. To confirm that telemetry surveys did not miss a potential spawning migration by a radio-tagged individual during a year in which it was defined as a resident, we confirmed that there were no PIT tag detections at the Willow Creek antenna array.

Choice of spawning tributary. We evaluated whether LRS and SNS showed a preference for a specific migratory path at the confluence of Willow and Boles Creeks. We used data for radio-tagged individuals that were detected in Boles and Upper Willow Creeks during years in which spawning tributaries were accessible. Data from 2015 were excluded from this analysis because all radio-tagged individuals were resident in Clear Lake. Because only 2 years (2016 and 2017) provided access to spawning tributaries during this study and data upstream from the confluence were limited, we also included data from a separate Clear Lake telemetry study in 2011 (USGS, unpub. data, 2011). In 2011, lake surface elevation was sufficient to provide access to Willow Creek from March to June.

Percentage of migrants and residents. During the February-May spawning season, we summarized the percentage of migrants and residents for radio-tagged suckers by species and sex each year. Our dataset included a combination of PIT tag and telemetry data that allowed a higher chance of detecting migratory behavior than from either data source alone. Migrants were defined as radio-tagged suckers that were confirmed to have active transmitters prior to spawning each year and were subsequently detected in Willow Creek or another tributary by PIT tag or telemetry detections during the spawning season. Residents were defined as radio-tagged suckers that were confirmed to have active transmitters prior to spawning and remained in Clear Lake over the duration of the spawning season based on a combination of PIT tag and telemetry data. No summary was necessary for 2015 given the lack of a spawning migration for either species. The 2016 summary included radio-tagged individuals released in autumn 2015 as well as radio-tagged individuals released in 2014 that survived until the 2016 spawning season. The 2017 summary included radio-tagged individuals released in autumn 2016 and radio-tagged individuals released in 2014 and 2015 that survived until the 2017 spawning season.

To assess whether lake surface elevation impeded access to Willow Creek each year, we compared the maximum lake surface elevation to the lake surface elevation known to impede access to spawning tributaries, approximately 1,379 m (4,424 ft). Lake level and access to Willow Creek is known to affect whether PIT-tagged adult suckers migrate to spawn (Burdick and others, 2018). Lake surface elevation data were acquired from Reclamation inventory using the "FD" parameter for CLK (https://www.usbr.gov/pn/hyromet/klamath/ arcread.html). 
Discrepancies in the sex ratio of adult LRS captured in autumn trammel net sampling compared to those detected at the Willow Creek PIT tag antennas have been documented (Hewitt and Hayes, 2013). This telemetry project attempted to have an equal representation of both sexes for each species. Although radio-tagged individuals were not meant to be representative of the entire LRS and SNS populations in Clear Lake, they were caught in autumn trammel net sampling and were expected to show migratory and residency behavior similar to that of fish with only PIT tags. We investigated the possibility of sex ratio discrepancies for each species between migrants and residents among radio-tagged individuals.

For radio-tagged individuals monitored for multiple spawning seasons, we summarized the percentage of individuals that were residents, migrants, or both in different years. Because sample sizes were small for individuals monitored for two spawning seasons, this was meant to investigate whether individuals may skip spawning in some years and migrate in other years using a combination of PIT tag and telemetry detections.

\section{Results}

\section{Lake Surface Elevation and Spawning Access}

Lake surface elevation was highly variable among years (fig. 3). There were more abrupt fluctuations at the Clear Lake Dam channel compared to the west lobe, particularly in winter and late summer in 2015 and 2016. At the dam channel site, no data were recorded from September 19 to October 2, 2017. In 2015, a small window occurred in early February for access to spawning tributaries, but only for LRS and SNS that were residing in the dam channel. In 2016 and 2017, lake surface elevations in the dam channel and west lobe provided access to spawning tributaries. The plateaus in lake surface elevation at the dam channel in January 2017 reflect overflow at the straits filling the west lobe.

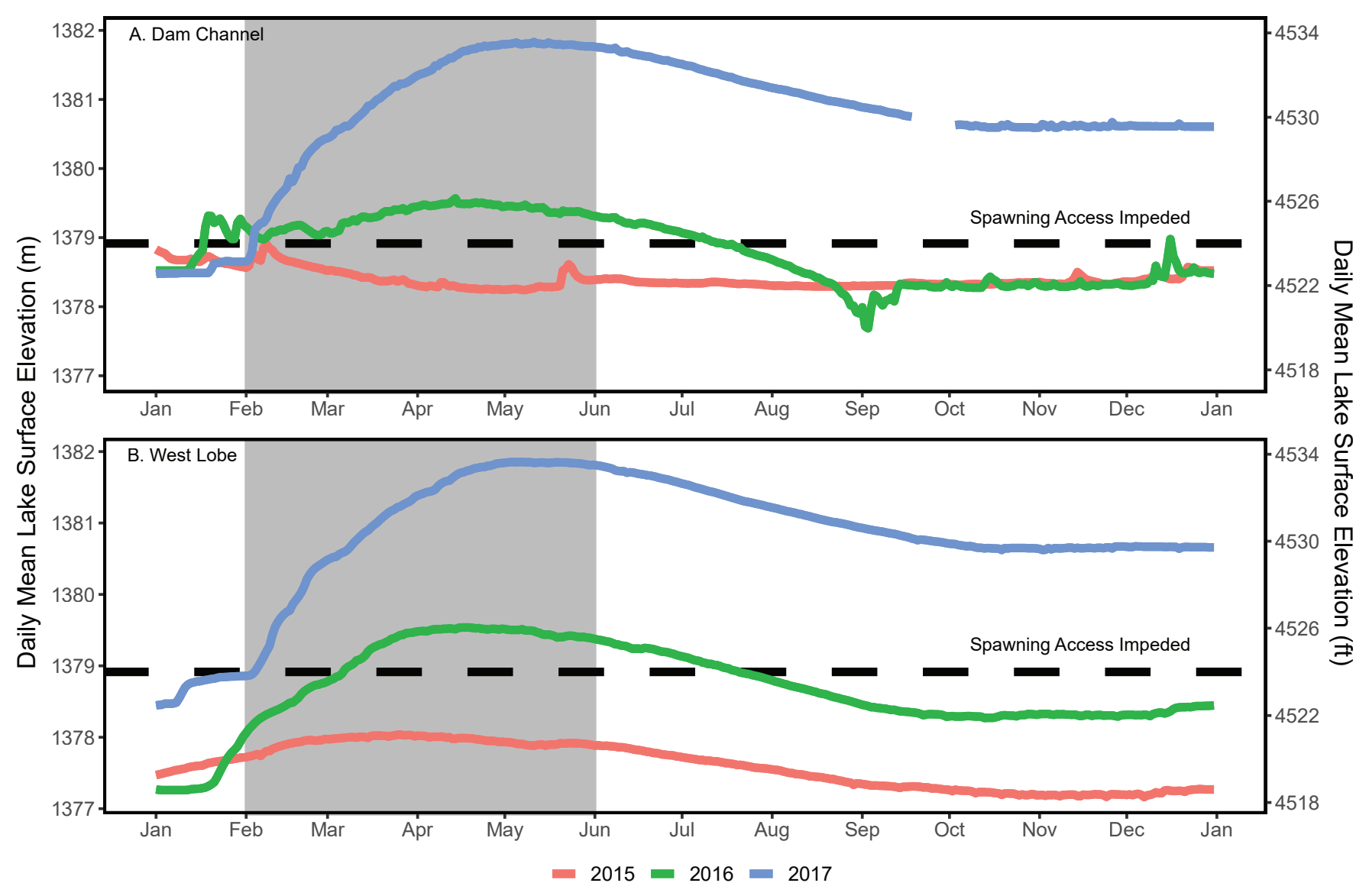

Figure 3. Lake surface elevations at the Dam Channel (A) and West Lobe (B) in Clear Lake Reservoir, California, 2015-17. Data from Bureau of Reclamation, accessed on April 1, 2018. Gray shading represents the spawning season for Clear Lake Lost River and shortnose sucker populations (February-May). Dashed line represents the approximate lake elevation referenced to Reclamation Vertical Datum specific to Clear Lake Reservoir in the Upper Klamath Basin when access to spawning tributaries is impeded at 1,379 meters ( $\mathrm{m} ; 4,524$ feet [ft]). 


\section{Remote PIT Tag Detections, Discharge, and Temperature in Willow Creek}

There were only seven LRS individuals detected at the Willow Creek PIT tag antenna array during the spawning season in 2015 (fig. 4). Because of the lack of migrating LRS, water temperature and discharge are presented, although no summaries were made. In 2016, 508 LRS were detected in Willow Creek during the spawning season. Detections peaked in mid-February. Discharge ranged from 3 to $1,559 \mathrm{ft}^{3} / \mathrm{s}$ during the spawning season; peak discharge occurred on January 29 (fig. 4A). Spawning migrations began when water temperatures reached $3{ }^{\circ} \mathrm{C}$ in early February and slowed when water temperatures were consistently greater than $10^{\circ} \mathrm{C}$ in early April (fig. 4B). In 2017, 814 LRS were detected in Willow Creek during the spawning season. Detections peaked in early March. Discharge ranged from 44 to $3,780 \mathrm{ft}^{3} / \mathrm{s}$ during the spawning season; peak discharge occurred in early February (fig. 4A). Spawning migrations began when water temperatures reached $2{ }^{\circ} \mathrm{C}$ in early February and ceased when water temperatures were consistently greater than $10^{\circ} \mathrm{C}$ in mid-April (fig. 4B).

There were only 29 SNS individuals detected at the Willow Creek array during the spawning season in 2015 (fig. 5). Because of the lack of migrating SNS, water temperature and discharge are presented, although no summaries were made. In 2016, 3,481 SNS were detected in Willow Creek during the spawning season. Like LRS, detections peaked in midFebruary. Spawning migrations began when water temperatures reached $2{ }^{\circ} \mathrm{C}$ in early February and ended when water temperatures were greater than $15^{\circ} \mathrm{C}$ in late April (fig. 5B). In 2017, 3,556 SNS were detected in Willow Creek during the spawning season. Detections peaked in early March. Spawning migrations began when water temperatures reached $2{ }^{\circ} \mathrm{C}$ in mid-February and slowed when water temperatures were consistently greater than $12{ }^{\circ} \mathrm{C}$ in early May (fig. 5B).

LRS Remote Detections and Discharge in Willow Creek

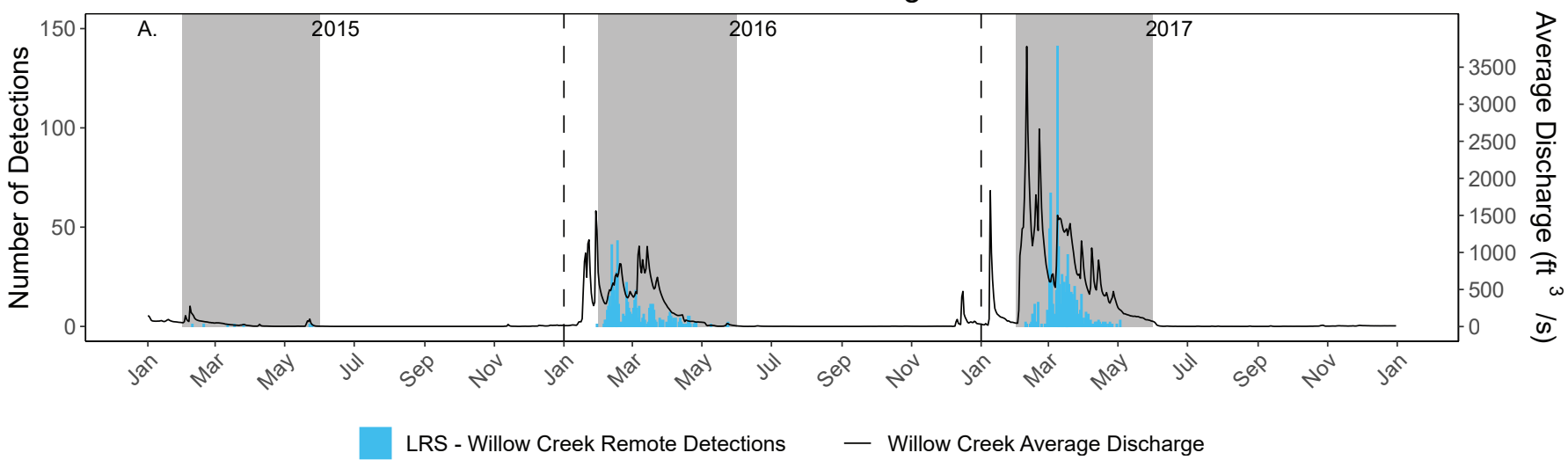

LRS Remote Detections and Temperature in Willow Creek

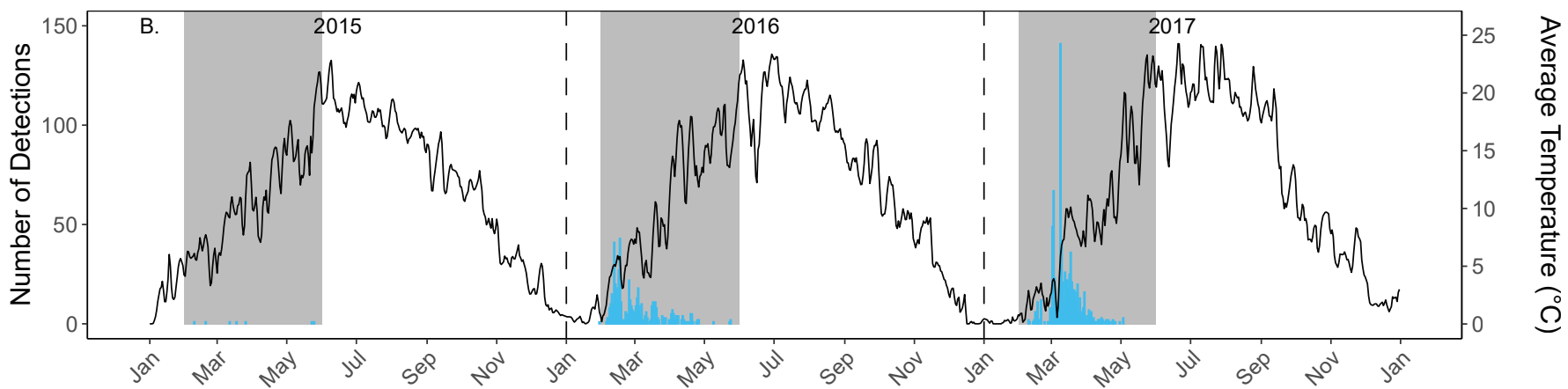

LRS - Willow Creek Remote Detections _ - Willow Creek Average Temperature

Figure 4. First detections of unique Lost River sucker (LRS) individuals at the remote Willow Creek passive integrated transponder tag antenna array, and average discharge (A) and average temperature (B) at the Bureau of Reclamation Hydromet station in Willow Creek (WILC), California, 2015-17. Regions shaded in gray represent the spawning season (February-May). [ $\mathrm{ft}^{3} / \mathrm{s}$, cubic feet per second; ${ }^{\circ} \mathrm{C}$, degrees Celsius.] 
SNS Remote Detections and Discharge in Willow Creek

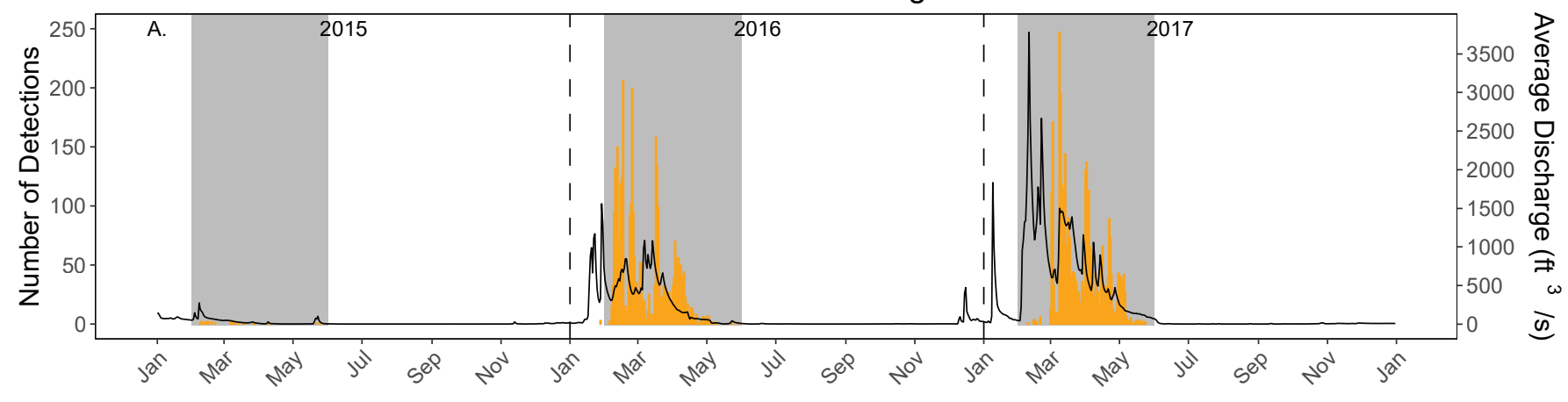

SNS - Willow Creek Remote Detections _ - Willow Creek Average Discharge

SNS Remote Detections and Temperature in Willow Creek

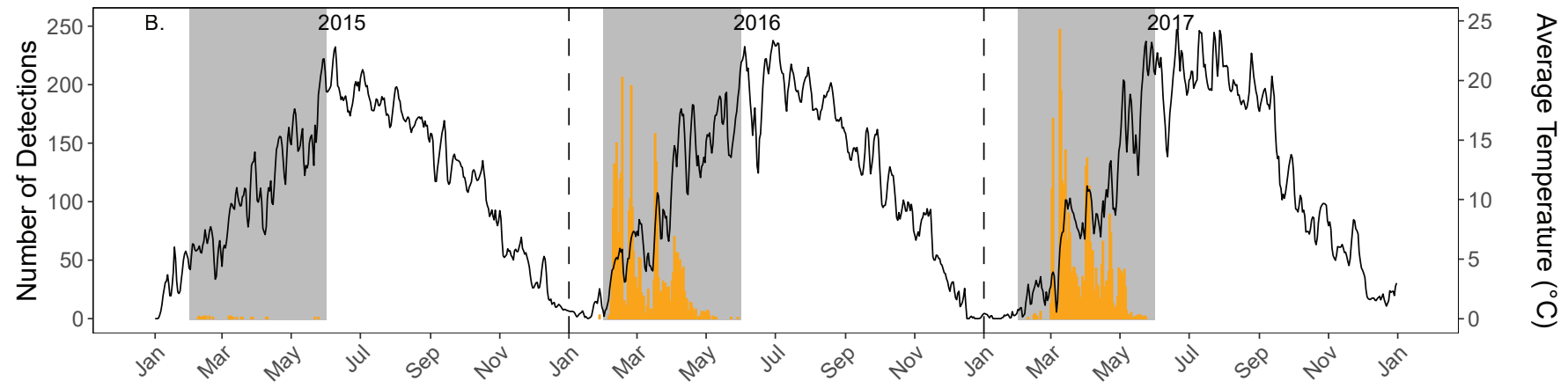

SNS - Willow Creek Remote Detections _ - Willow Creek Average Temperature

Figure 5. First detections of unique shortnose sucker (SNS) individuals at the remote Willow Creek passive integrated transponder tag antenna array, and average discharge (A) and average temperature (B) at the Bureau of Reclamation Hydromet station in Willow Creek (WILC), California, 2015-17. Regions shaded in gray represent the spawning season (February-May). [ft3/s, cubic feet per second; ${ }^{\circ} \mathrm{C}$, degrees Celsius.]

Table 2. Number of suckers captured and implanted with radio transmitters by species and sex in Clear Lake, California, in autumn of 2014, 2015, and 2016.

\begin{tabular}{crrrrc}
\hline \multirow{2}{*}{ Year } & \multicolumn{2}{c}{ LRS } & \multicolumn{2}{c}{ SNS } & Total \\
\cline { 2 - 6 } & F & M & F & M & n \\
\hline 2014 & 16 & 16 & 22 & 21 & 75 \\
2015 & 13 & 13 & 20 & 18 & 64 \\
2016 & 7 & 3 & 3 & 11 & 24 \\
Total & 36 & 32 & 45 & 50 & 163 \\
\hline
\end{tabular}

\section{Capture and Tagging Summary}

A total of 163 suckers (68 LRS and 95 SNS) were captured in the west lobe of Clear Lake and implanted with radio transmitters during the autumns of 2014-2016 (table 2). Because of high mortality during 2015, many fish were tagged in autumn 2015 to replace lost individuals. Given lower mortality in 2016, fewer new individuals were tagged in the autumn of 2016. For LRS, fork lengths ranged from 464 to $671 \mathrm{~mm}$ for females and 470 to $588 \mathrm{~mm}$ for males (fig. 6). For SNS, fork lengths ranged from 326 to $469 \mathrm{~mm}$ for females and 308 to $454 \mathrm{~mm}$ for males (fig. 6).

\section{Relocation Histories}

Relocation histories of 16 radio-tagged LRS females released in 2014 showed that all tags were detected on multiple surveys in 2015 (fig. 7). The survey on February 25, 2015 detected few transmitters overall and none of the transmitters in LRS females for unknown reasons. A total of 12 transmitters (75 percent) were not detected beyond 2015 owing to unknown causes ( 37 percent), avian mortality (13 percent), and other mortalities ( 25 percent). The remaining four LRS females ( 25 percent) were detected in 2016 . Of these, three were not detected beyond 2016 owing to mortality (13 percent) or the probability of an expelled transmitter (6 percent). In 2017, the one remaining transmitter was assumed to have a dead battery and final detection occurred on May 24, 2017. 


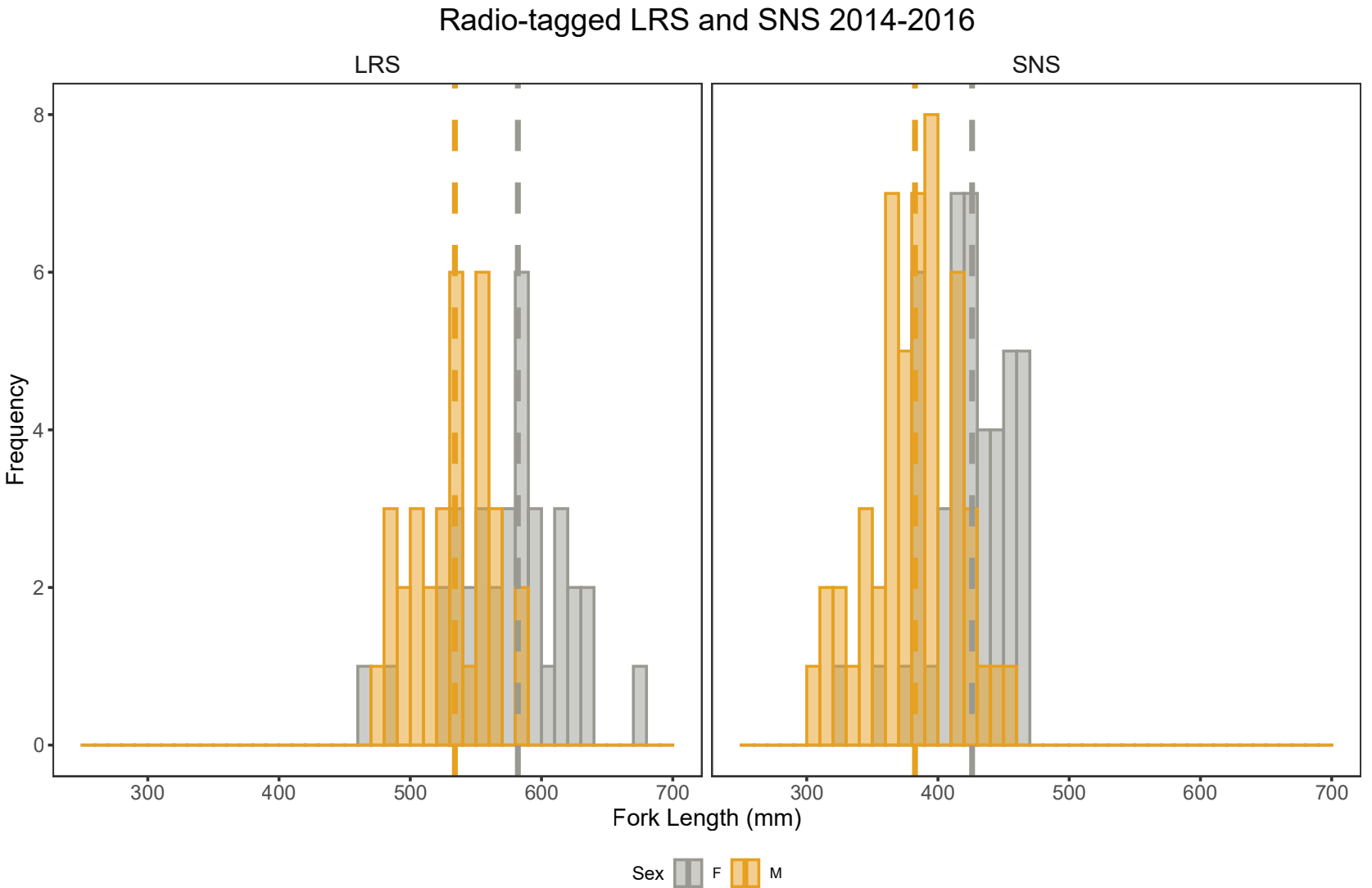

Figure 6. Fork lengths of Lost River and shortnose suckers (LRS and SNS) implanted with radio transmitters in Clear Lake, California, 2014-16. Dashed lines represent the median fork lengths, by sex. [F, female; M, male; mm, millimeters.]

Relocation histories of 13 radio-tagged LRS females released in 2015 (fig. 7) showed that one transmitter was never detected following release ( 8 percent), and that the remaining transmitters were detected on multiple surveys in 2016 (92 percent). In 2016, there were three mortalities (23 percent), one unknown fate ( 8 percent), and eight transmitters that were still active (62 percent). In 2017, there were two mortalities (15 percent), one unknown fate ( 8 percent), and five transmitters that were still active in 2018 (38 percent).

Seven radio-tagged LRS females were released in 2016 (fig. 7). One was never detected following release (14 percent). The remaining six transmitters were detected on multiple surveys in 2017. Of these, one was an unknown fate (14 percent) and five transmitters were active through 2017 (71 percent). Few transmitters were detected on the March 28, 2017 survey for unknown reasons. In 2018, there was one unknown fate (14 percent), three mortalities (43 percent), and one active transmitter (14 percent).

Relocation histories of 16 radio-tagged LRS males released in 2014 showed that all tags were detected on multiple surveys in 2015 (fig. 8). A total of nine LRS males (56 percent) were not detected beyond 2015 owing to unknown causes (19 percent) and mortality (37 percent). The remaining seven LRS males (44 percent) were detected on multiple surveys in 2016. Six were not detected beyond 2016 owing to unknown causes (19 percent), the probability of an expelled transmitter (6 percent), and other mortalities (13 percent). In 2017, the one remaining transmitter was assumed to have a dead transmitter battery and final detection occurred on May 24, 2017. This transmitter (164.290; fig. 8) was unique in that it was detected in 2015 and 2017 from telemetry surveys, but was not detected in 2016. Interestingly, this fish had PIT tag detections at the straits and Willow Creek PIT tag antenna arrays in 2016.

Relocation histories of 13 radio-tagged LRS males released in 2015 (fig. 8) showed that one transmitter was never detected following release ( 8 percent), and that the remaining transmitters were detected and active on multiple surveys through 2016. In 2017, there were four mortalities ( 31 percent), three unknown fates ( 23 percent), and five transmitters that were assumed to be active through 2018 (38 percent). None of the active tags were detected on the final three surveys.

Three radio-tagged LRS males were released in 2016 (fig. 8). All were detected and active in 2017; they were encountered regularly during surveys. In 2018, one mortality (33 percent) occurred and two transmitters were still active (67 percent). 
Relocation histories of 22 radio-tagged SNS females released in 2014 showed that three transmitters were never detected following release (14 percent) and the remaining transmitters were detected on multiple surveys in 2015 (fig. 9). A total of 12 SNS females (55 percent) were not detected beyond 2015 owing to unknown causes (14 percent), avian mortality ( 9 percent), and other mortality (32 percent). The remaining seven SNS females (32 percent) were detected in 2016. Of these, five ( 23 percent) were not detected beyond 2016 due to unknown causes ( 5 percent), mortality (9 percent), and the probability of an expelled transmitter (9 percent). Of the remaining two transmitters in 2017 , one mortality occurred ( 5 percent) and the other remained active but was assumed to have a dead battery in 2018 ( 5 percent).

Relocation histories of 20 radio-tagged SNS females released in 2015 showed that all transmitters were detected on multiple surveys in 2016 (fig. 9). A total of 11 SNS females (55 percent) were not detected beyond 2016 owing to unknown causes (10 percent), the probability of an expelled transmitter (15 percent), and mortality (30 percent). The remaining nine SNS females were active through 2016 (45 percent). In 2017, there were three mortalities (15 percent), four unknown fates ( 20 percent), and two transmitters that were assumed to be active through 2018 (10 percent). None of the active tags were detected on the final two surveys. One mortality from avian predation possibly occurred in 2017 (164.230 84; fig. 9) near the islands in the east lobe, although this was not confirmed.

Three radio-tagged SNS females were released in 2016 (fig. 9). All were regularly detected during surveys in 2017. In 2017, one was assumed to be a mortality (33 percent) and the remaining two transmitters were active through 2018 (67 percent).

Relocation histories of 21 radio-tagged SNS males released in 2014 showed that two transmitters were never detected following release ( 9 percent) and the remaining transmitters were detected on multiple surveys in 2015 (fig. 10). A total of 13 SNS males (62 percent) were not detected beyond 2015 owing to unknown causes (5 percent), avian mortality (10 percent), the probability of an expelled transmitter (14 percent), and other mortality (33 percent). The remaining six SNS males ( 28 percent) were detected in 2016 . Of these, three (14 percent) were not detected beyond 2016 owing to unknown causes ( 9 percent) and mortality ( 5 percent). In 2017 , the remaining three transmitters were either assumed mortalities (9 percent) or an expelled transmitter ( 5 percent).

Relocation histories of 18 radio-tagged SNS males from 2015 (fig. 10) showed that two transmitters (11 percent) were never detected following release, one transmitter was a confirmed mortality soon after release ( 5 percent), and the remaining transmitters were detected on multiple surveys in 2016. A total of 10 SNS males ( 55 percent) were not detected beyond 2016 owing either to a mortality (44 percent) or a probable expelled transmitter (11 percent). Interestingly, one radio tag (164.290 124; fig. 10) had a presumed tag expulsion in September 2016, with later detections on the straits PIT tag antenna array in 2016 and the Willow Creek array in 2017. The transmitter was never recovered, but the PIT tag was later detected on a bird colony in the east lobe of Clear Lake in autumn 2018. In 2017, fates of the remaining transmitters from the 2015 SNS male cohort included two mortalities (11 percent), one expelled transmitter (5 percent), and two active tags through 2017 (11 percent). In 2018, the two remaining tags were either a mortality or an unknown fate.

Eleven radio-tagged SNS males were released in 2016 (fig. 10). Every transmitter was detected in 2017 and there were two mortalities (18 percent). In 2018, the remaining nine transmitters were assumed to be active except for one mortality ( 9 percent) and one unknown fate ( 9 percent).

Mortalities from unknown causes constituted approximately 45 percent of the total across all tagged individuals (LRS female, 39 percent; LRS male, 41 percent; SNS female, 44 percent; SNS male, 50 percent). Radio tags that likely were expelled were also similar between sexes but higher for SNS compared to LRS (LRS female, 3 percent; LRS male, 3 percent; SNS female, 11 percent; SNS male, 14 percent). Avian mortalities occurred only in 2015 and accounted for 4 percent of individual fates.

\section{Expelled Transmitters}

One radio-tagged SNS male was recaptured twice in autumn trammel net sampling (2014 and 2016). Identification was confirmed by PIT tag detection and photographs were taken on each occasion. The first recapture occurred 6 days after radio-tagging on October 20, 2014 and shows evidence of the implanted radio tag with sutures intact and the antenna wire (fig. 11). The second recapture occurred approximately two years later on October 12, 2016 and showed no sign of a radio tag or antenna along with a concave depression at the site of the incision. There also were two visible holes in the body wall, indicative of the possible expulsion site and an associated infection. Other radio-tagged fish were not recaptured in autumn trammel net sampling.

\section{Seasonal Spatial and Temporal Distribution}

For suckers radio-tagged and released in Clear Lake Reservoir (2014-16), spatial distributions by time period showed a pattern of using Clear Lake as a home lake during pre-spawning, migrating out of the lake during spawning if lake surface elevations provided access to spawning tributaries, and returning to the lake after spawning (figs. 12 and 13). The exception to this pattern was 2015, when access to spawning tributaries was impeded by lake surface elevation throughout the spawning season and low inflows resulted in most of the east lobe becoming dry by late summer. 


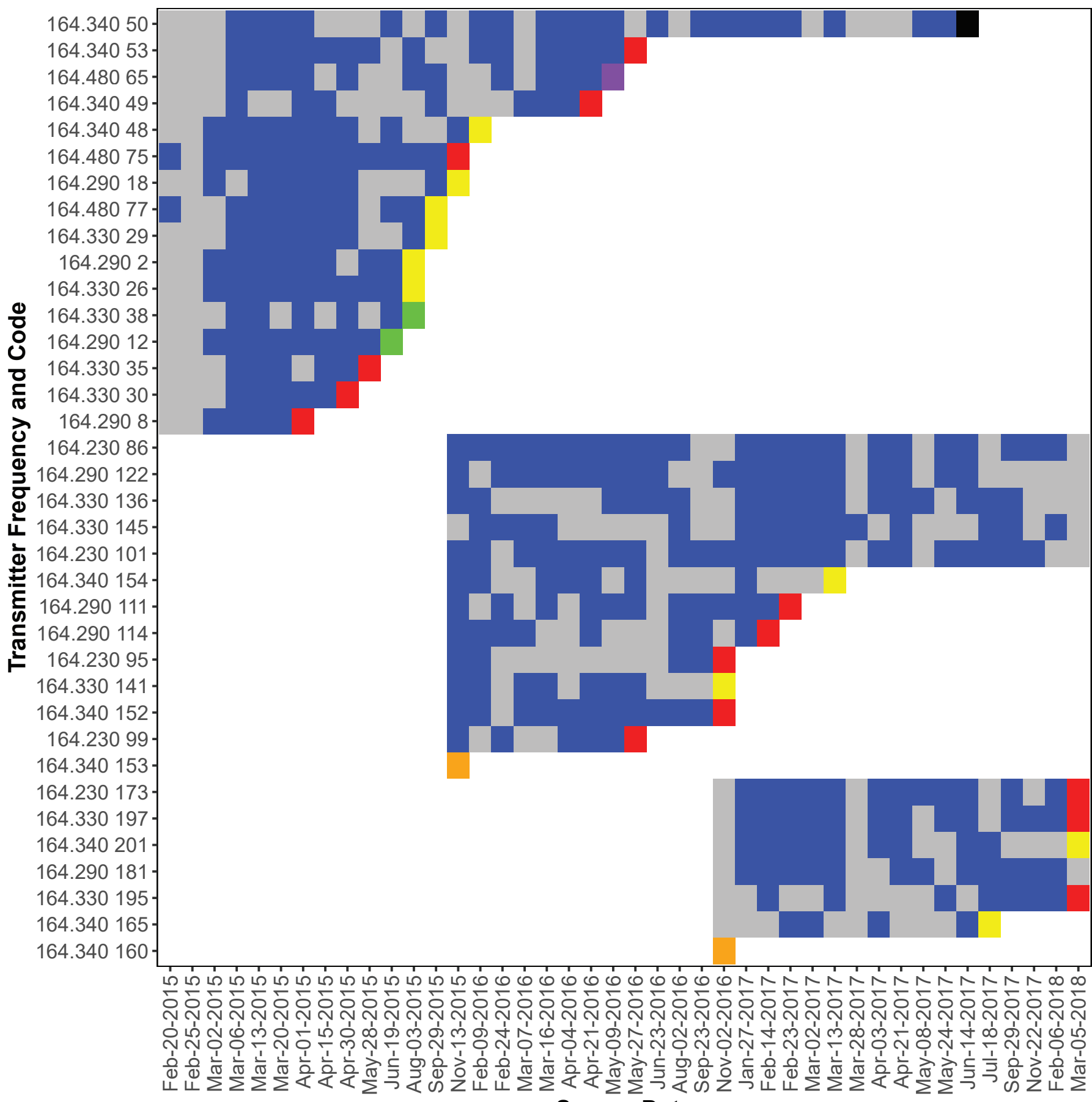

\section{Survey Date}

$\begin{array}{llll}\text { Never Detected } & \text { Detected } & \text { Mortality } & \text { Probable Expulsion } \\ \text { Missed } & \text { Unknown } & \text { Avian Mortality } & \text { Probable Dead Battery }\end{array}$

Figure 7. Relocation histories of Lost River sucker females implanted with radio transmitters in Clear Lake, California, in autumn of 2014, 2015, and 2016. Tag 164.340160 also was used in a shortnose sucker male in 2015. The tag in the SNS male was shed 2 weeks after release, was assumed to have been a mortality, and was cleaned and reused in 2016. 


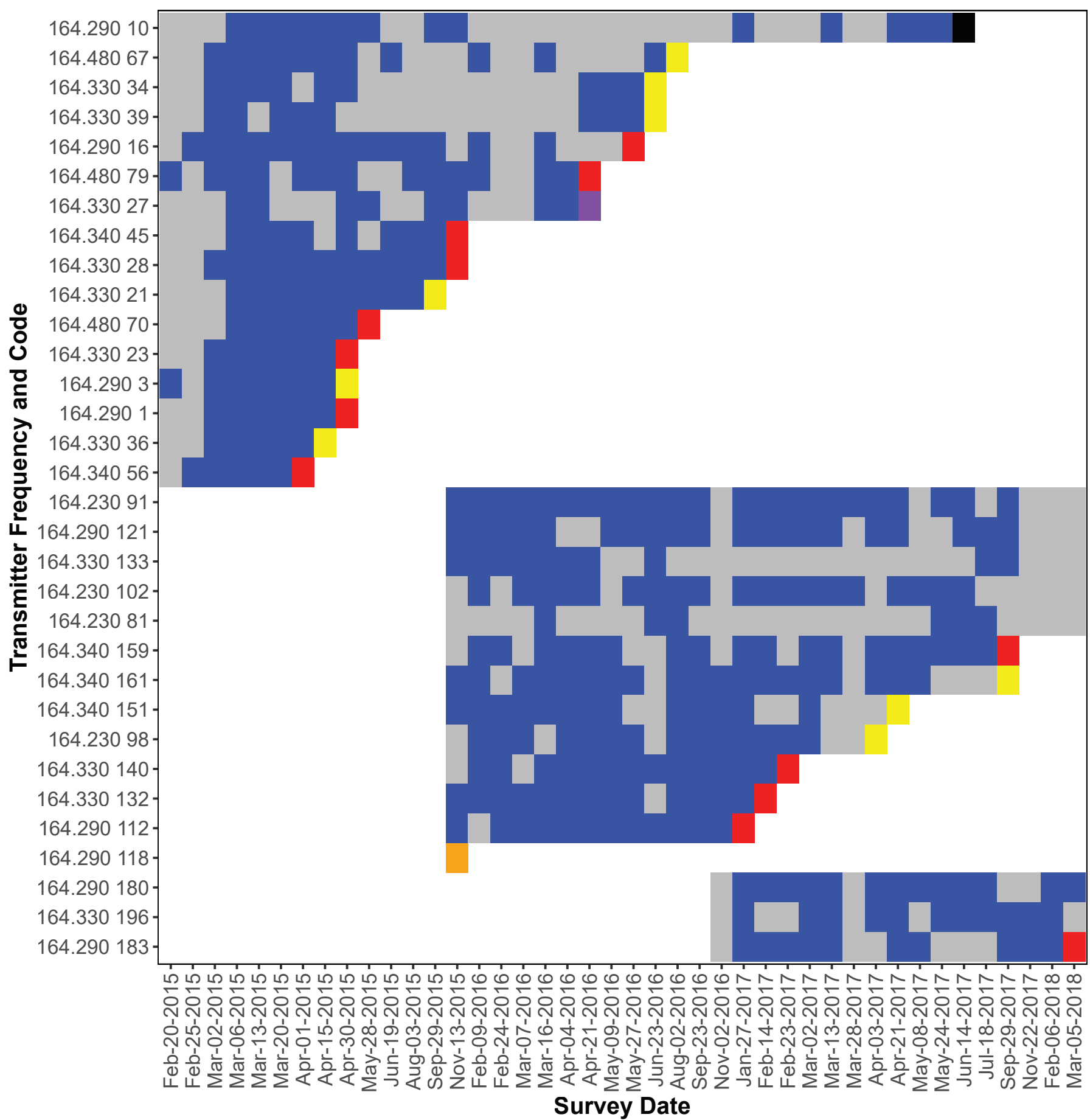

Never Detected Missed

\section{Survey Date}

Detected
Unknown

Mortality

Probable Expulsion
Probable Dead Battery

Figure 8. Relocation histories of Lost River sucker males implanted with radio transmitters in Clear Lake, California, in autumn of 2014, 2015, and 2016. 


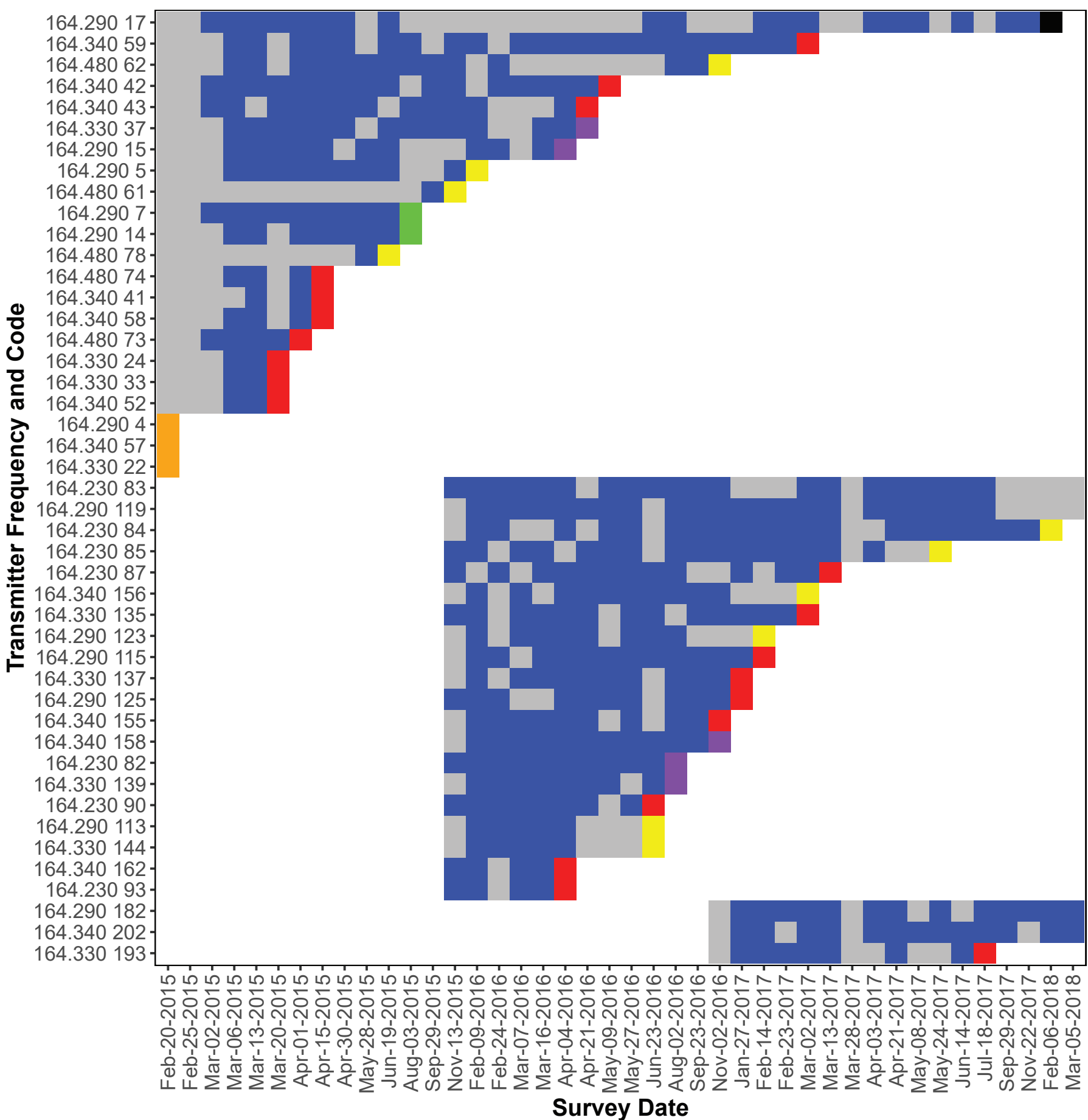

\section{Survey Date}

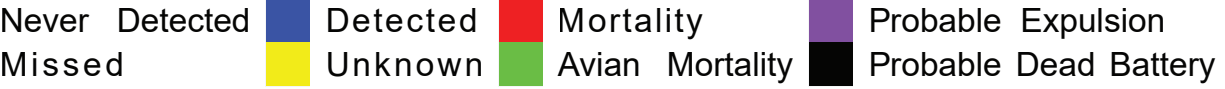

Figure 9. Relocation histories of shortnose sucker females implanted with radio transmitters in Clear Lake, California, in autumn of 2014, 2015, and 2016 . 


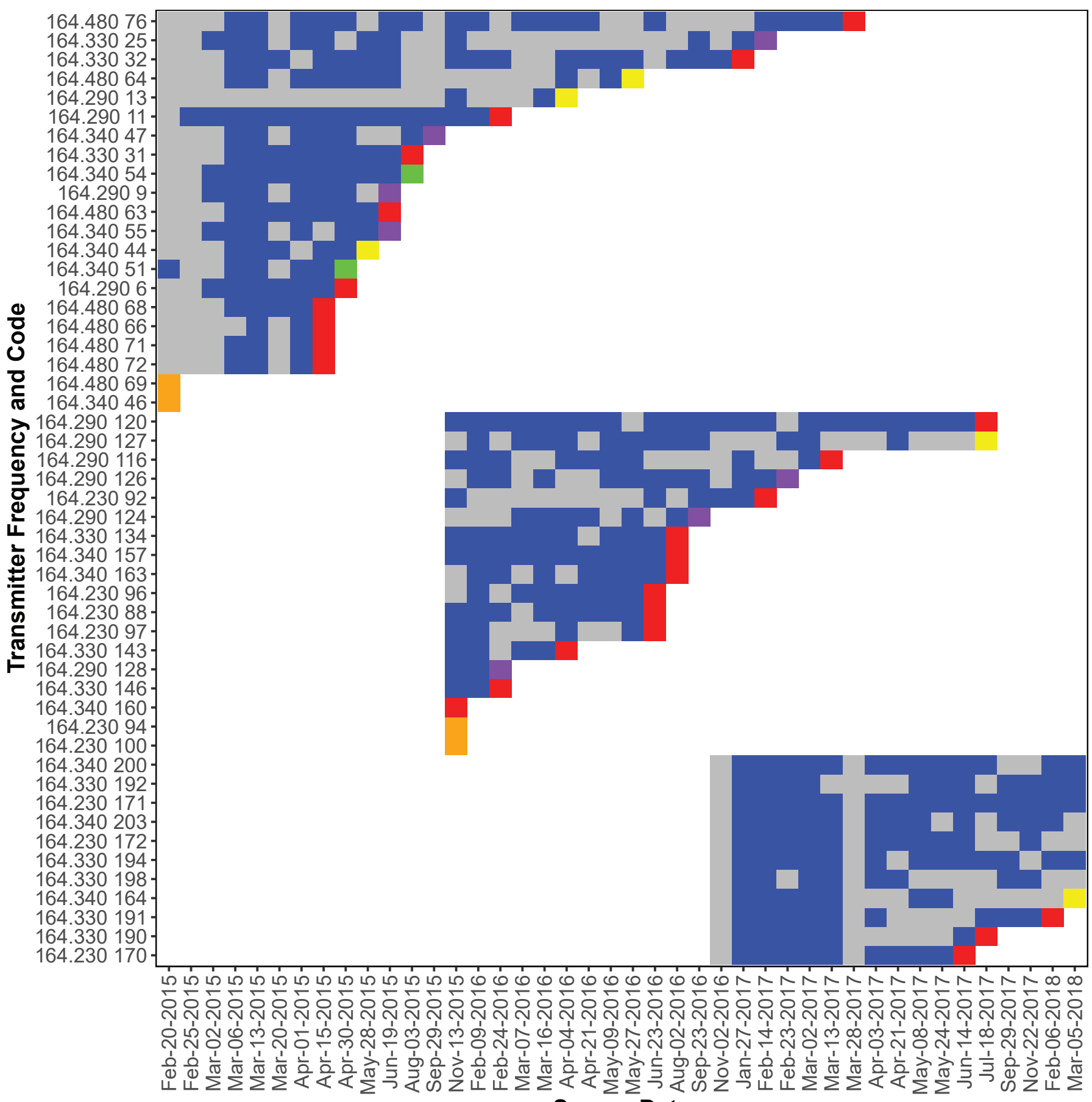

Survey Date

$\begin{array}{llll}\text { Never Detected } & \text { Detected } & \text { Mortality } & \text { Probable Expulsion } \\ \text { Missed } & \text { Unknown } & \text { Avian Mortality }\end{array}$

Figure 10. Relocation histories of shortnose sucker males implanted with radio transmitters in Clear Lake, California, in autumn of 2014,2015 , and 2016. 

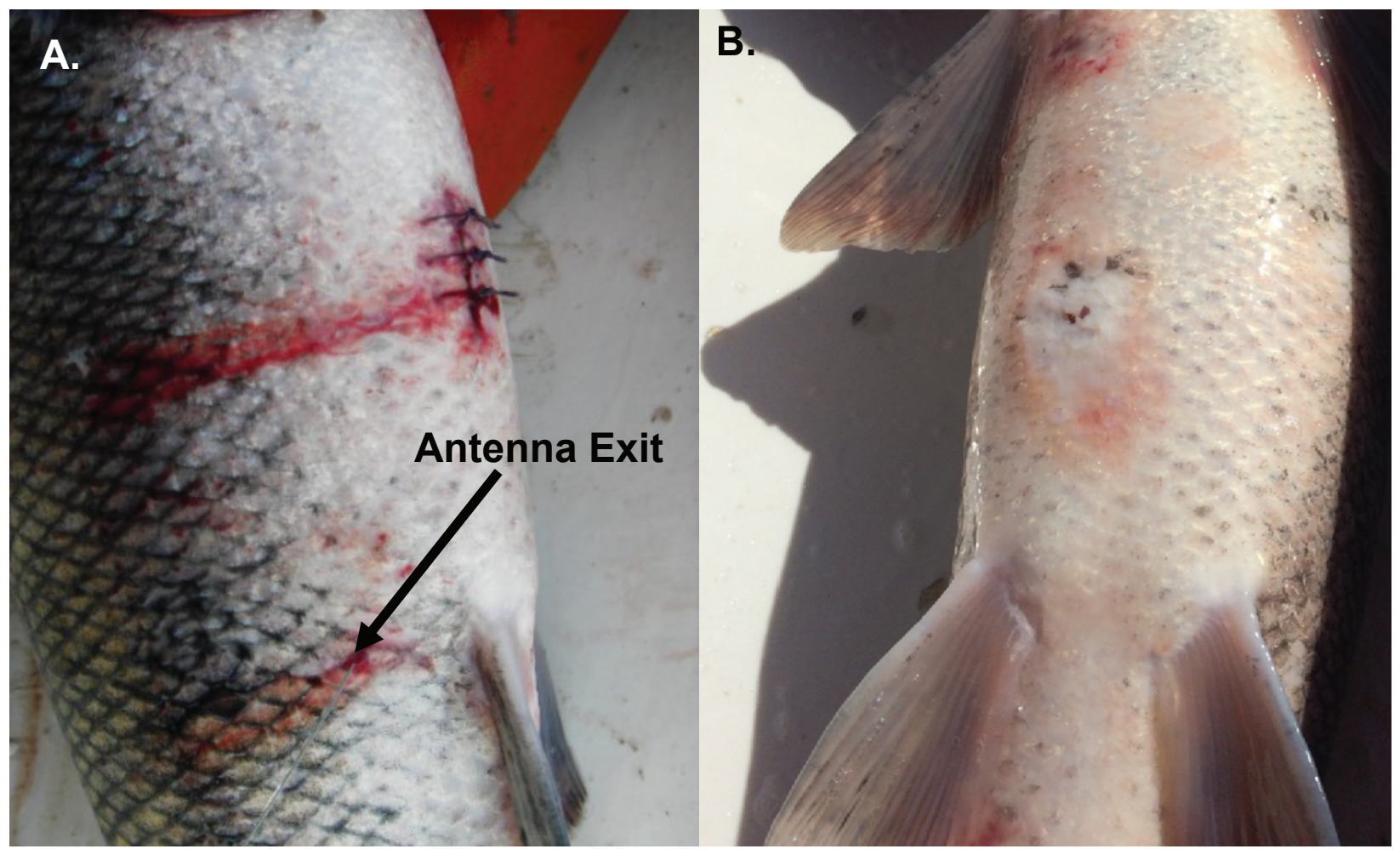

Figure 11. Photographs by the U.S. Geological Survey showing a shortnose sucker male recaptured in Clear Lake, California, 6 days after surgery on October 20, 2014, with the radio transmitter (A), and recaptured again on October 12, 2016, with no visible signs of the radio transmitter (B).

In 2015, most LRS and SNS remained in the west lobe of Clear Lake during pre-spawning, spawning, and postspawning. During the pre-spawning period, an aggregation of eight LRS ( 2 females; 6 males) occurred in the east lobe near the Willow Creek mouth. Only two SNS were located in the east lobe during pre-spawning with the remaining SNS along the shoreline of the west lobe. Although more LRS were observed in the east lobe during spawning, none were observed in the spawning tributaries. One LRS female was located in the channel near the dam. No SNS were observed in the east lobe or in the spawning tributaries during the spawning season in 2015. During the post-spawning period, no LRS and SNS were detected in the east lobe of Clear Lake as water levels receded and later exposed a mostly dry east lobe in 2015.

In 2016, access to spawning tributaries was intermittently available for fish in the dam channel in January and February but impeded by low lake-surface elevation until March (fig. 3). During pre-spawning and in contrast to 2015, LRS and SNS were evenly distributed in the east and west lobes. There was one early migrating LRS male in Willow Creek during the time period defined as pre-spawning. Most suckers were later observed migrating out of Clear Lake to spawn. During spawning, most LRS (76 percent of females; 54 percent of males) and SNS ( 83 percent of females; 60 percent of males) were observed in spawning tributaries. SNS migrated farther than LRS in Boles and Willow Creeks. During post-spawning, most LRS and SNS returned to Clear Lake and were observed in both the east and west lobes with the exception of several mortalities detailed in the section, "Farthest Upstream Spawning Location."

In 2017, access to spawning tributaries was impeded by low lake surface elevation until February (fig. 3). During pre-spawning, LRS and SNS used the east and west lobes of Clear Lake as they did in 2016. Most suckers were observed migrating out of Clear Lake to spawn. During spawning, most LRS (76 percent of females; 62 percent of males) and SNS (73 percent of females; 94 percent of males) were observed in spawning tributaries. Like in 2016, SNS migrated farther than LRS in Boles and Willow Creeks in 2017, although fewer SNS were observed in Boles Creek compared to 2016 and all were male. Three SNS were detected in the Fourmile Creek drainage, a tributary to upper Willow Creek. No LRS were found in the Fourmile Creek drainage in 2016 or 2017. After spawning, most LRS and SNS returned to Clear Lake and were observed in both the east and west lobes of the reservoir, with the exception of several mortalities detailed in the section, "Farthest Upstream Spawning Location.” 

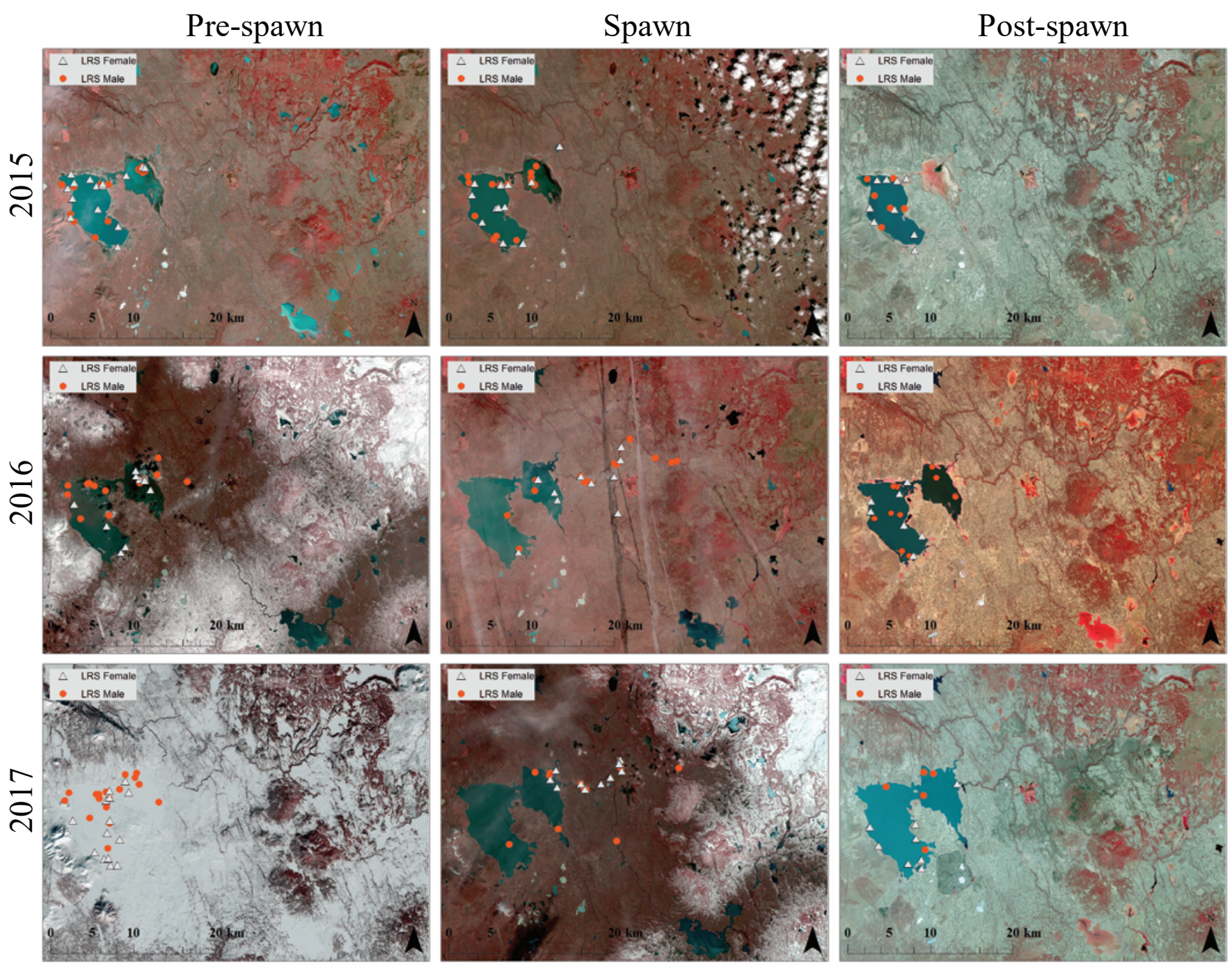

Figure 12. Seasonal distribution of Lost River suckers (LRS) during pre-spawning, spawning, and post-spawning periods, Clear Lake, California, 2015-17. [Note: Pre-spawning imagery in 2017 shows extensive snow and ice coverage in the Clear Lake watershed. Locations of radio-tagged fish represent under-ice distributions in Clear Lake.]

\section{Farthest Upstream Spawning Location}

Among radio-tagged LRS, 32 migrated out of Clear Lake during the spawning seasons in 2016 and 2017, primarily within mainstem reaches of Willow Creek (fig. 14). Of these, the farthest upstream location for 13 LRS was in Lower Willow Creek. Of the remaining 19 LRS that migrated, 15 migrated to Upper Willow Creek ( 7 females; 8 males), and 4 migrated into Boles Creek ( 3 females; 1 male). All LRS returned to Clear Lake after spawning. The most upstream migrant in the Boles Creek system, an LRS male (164.290 10 ) in 2017, was initially assumed to be a mortality in Boles Creek. However, its last telemetry detection on May 24, 2017, was estimated to be at the end of the expected battery life. There were no PIT tag detections for this individual on the Willow Creek antenna array after May 24, 2017, but the remote antenna array may have missed detecting the PIT tag because of high flows in 2017. Therefore, the final fate of this fish is a probable dead battery.

Radio-tagged SNS migrated farther upstream in Boles and Willow Creeks compared to LRS. A total of 45 SNS migrated out of Clear Lake during the spawning seasons in 2016 and 2017 (fig. 14). Of these, the farthest upstream location for 20 SNS was in Lower Willow Creek. Of the remaining 25 SNS that migrated, 12 were located in Upper Willow Creek ( 8 females; 4 males), and 13 were found in Boles Creek (7 females; 6 males). The farthest SNS migrants in the Upper Willow Creek system did not return to Clear Lake after the spawning seasons in 2016 ( 1 female) and 2017 (1 female; 1 male). These three fish migrated to Fourmile and Wildhorse Creeks, two tributaries to Upper Willow Creek (figs. 1 and 14). All three transmitters were recovered following the spawning season in June 2017, assumed to be mortalities. Recovered transmitters were not later determined to be expelled. Two 

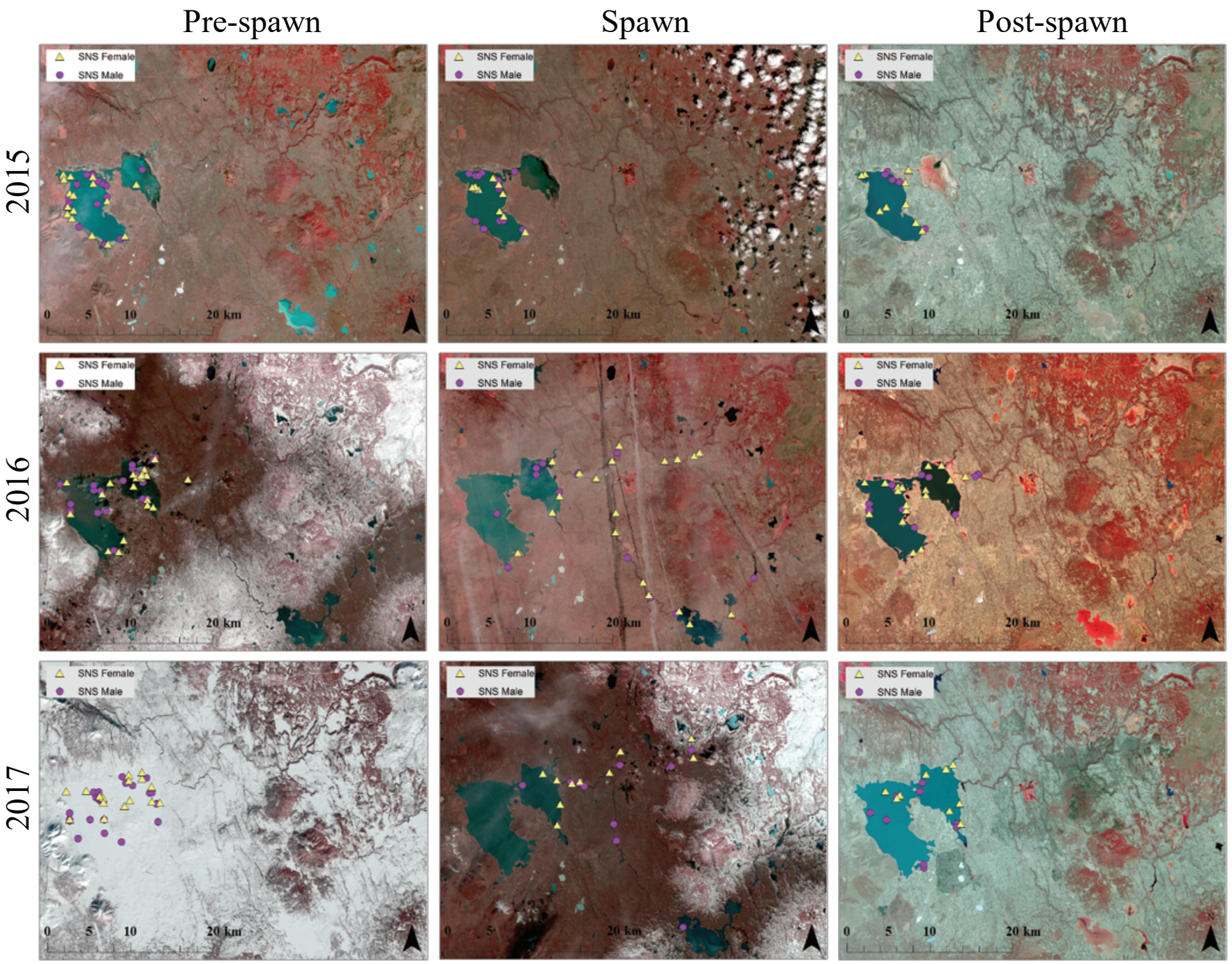

Figure 13. Seasonal distribution of shortnose suckers (SNS) during pre-spawning, spawning, and post-spawning periods, Clear Lake, California, 2015-17. [Note: Pre-spawning imagery in 2017 shows extensive snow and ice coverage in the Clear Lake watershed. Locations of radio-tagged fish represent under-ice distributions in Clear Lake.]

transmitters were recovered in dry areas of the Fourmile Creek drainage (164.230 90, SNS female; 164.330 190, SNS male) and one transmitter was found in a reservoir created by a dam at the confluence of Fourmile and Wildhorse Creeks (164.330 193, SNS female). One female SNS was confirmed to have migrated into Fourmile/Wildhorse Creeks in 2016, although the transmitter was not recovered until 2017 (164.230 90). The other two SNS were mortalities in 2017. All of these mortalities occurred within $3 \mathrm{~km}$ of the Willow Creek mainstem. The remaining SNS that migrated into the mainstem of Upper Willow Creek returned to Clear Lake.

The farthest SNS migrants in the Boles Creek system did not return to Clear Lake after the spawning seasons in 2016 (3 females; 3 males; fig. 14) and 2017 (2 males; fig. 14). Two SNS females were last detected in Boles Meadow, a shallow ephemeral marsh, in 2016 (164.340 42 and 164.330 144). Two SNS (1 female; 1 male) migrated as far as Fletcher and Avanzino Reservoirs in 2016. The male SNS that migrated to Avanzino Reservoir (164.330 134) was later confirmed as a mortality in Boles Meadow and the SNS female (164.290 113) was confirmed as a mortality in lower Fletcher Reservoir. Two SNS males were last detected immediately downstream from the head gates of Boles Meadow, one in 2016 (164.340 $163)$ and the other in 2017 (164.290 120). Two other SNS males migrated and were mortalities in Boles Creek downstream from Boles Meadow, one in 2016 and one in 2017. One (164.340 157) migrated as far as the Mowitz Road crossing of Boles Creek but was a mortality approximately 2 months later just upstream from the Willow Creek antenna array in 2016. The other (164.230 170) migrated as far as Clear Lake Reservoir Road with mortality occurring immediately downstream from the road crossing in 2017. The only other confirmed mortality in the tributaries was another SNS male (164.230 88) that was $<2 \mathrm{~km}$ from Clear Lake and downstream from the Willow Creek PIT tag antenna array in 2016 (fig. 14). 


\section{Tributary Spawning Distribution}
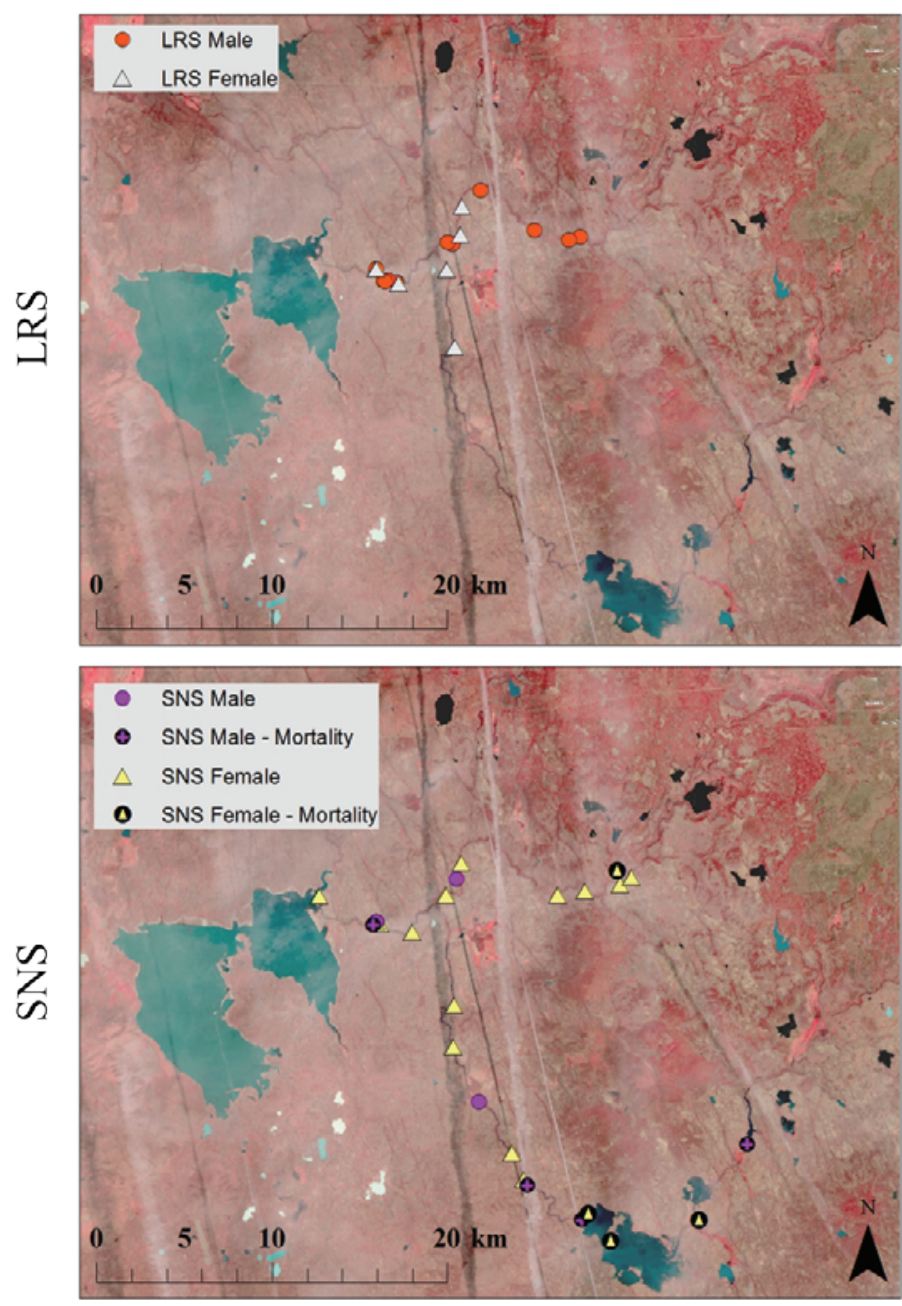

2017 Tributary Spawning Distribution
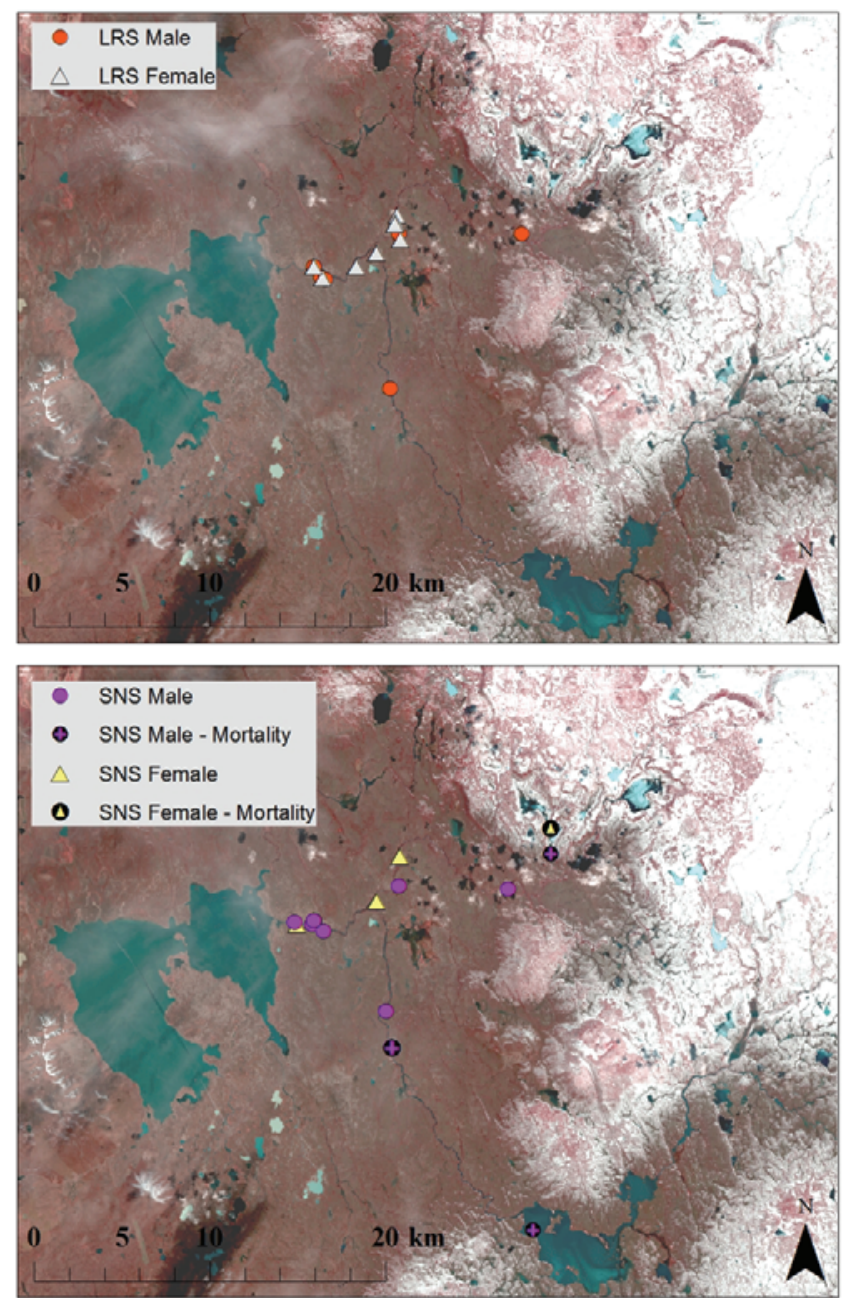

Figure 14. Farthest upstream location of radio-tagged Lost River and shortnose suckers (LRS and SNS) during spawning seasons, Clear Lake watershed, California, 2016-17. No documented spawning migration occurred in 2015 owing to low water levels.

Timing of SNS mortalities in tributaries typically occurred in spring during April-May in 2016. Two SNS females $(134.290113 ; 164.330144)$ had estimated mortalities on April 4, 2016, upstream from the Boles Meadow head gates. Another SNS female (164.340 42) had an estimated mortality on April 21, 2016, in Boles Meadow. In Wildhorse Creek, an SNS female (164.230 90) had an estimated mortality between April 21 and June 23, 2016. This area was not surveyed specifically in 2017 so timing of actual mortality could not be determined, although a weak tag signal was detected during surveys directly over Upper Willow Creek. One SNS male (164.340 163) had an estimated mortality on April 21, 2016, downstream from the Boles Meadow head gates. Another SNS male (154.330 134) had an estimated mortality on May 9, 2016, in Boles Meadow. There were two SNS males (164. 23088 and 164.340 157) that had estimated mortalities on April 21, 2016, near the Willow Creek remote antenna array.
Fewer SNS mortalities occurred in 2017, perhaps owing to higher flows, although estimated mortalities occurred in spring. One SNS female (164.330 193) and one SNS male (164.330 190) were mortalities in Wildhorse Creek during spring 2017, although surveys over this creek were not done until June 14, 2017. Another SNS male (164.290 120) had an estimated mortality in Boles Meadow on May 8, 2017.

\section{Individual Movement and Migration Tracks}

Locations of two LRS, one female and male, were plotted as movement and migration tracks by year (fig. 15). The LRS female (164.340 50), tagged in the autumn of 2014, showed residency movements in the west lobe of Clear Lake from March 3 to September 29, 2015. Similarly, this same female LRS was resident in Clear Lake in 2016 moving between the west and east lobes from February 9 to November 2, 2016. In 

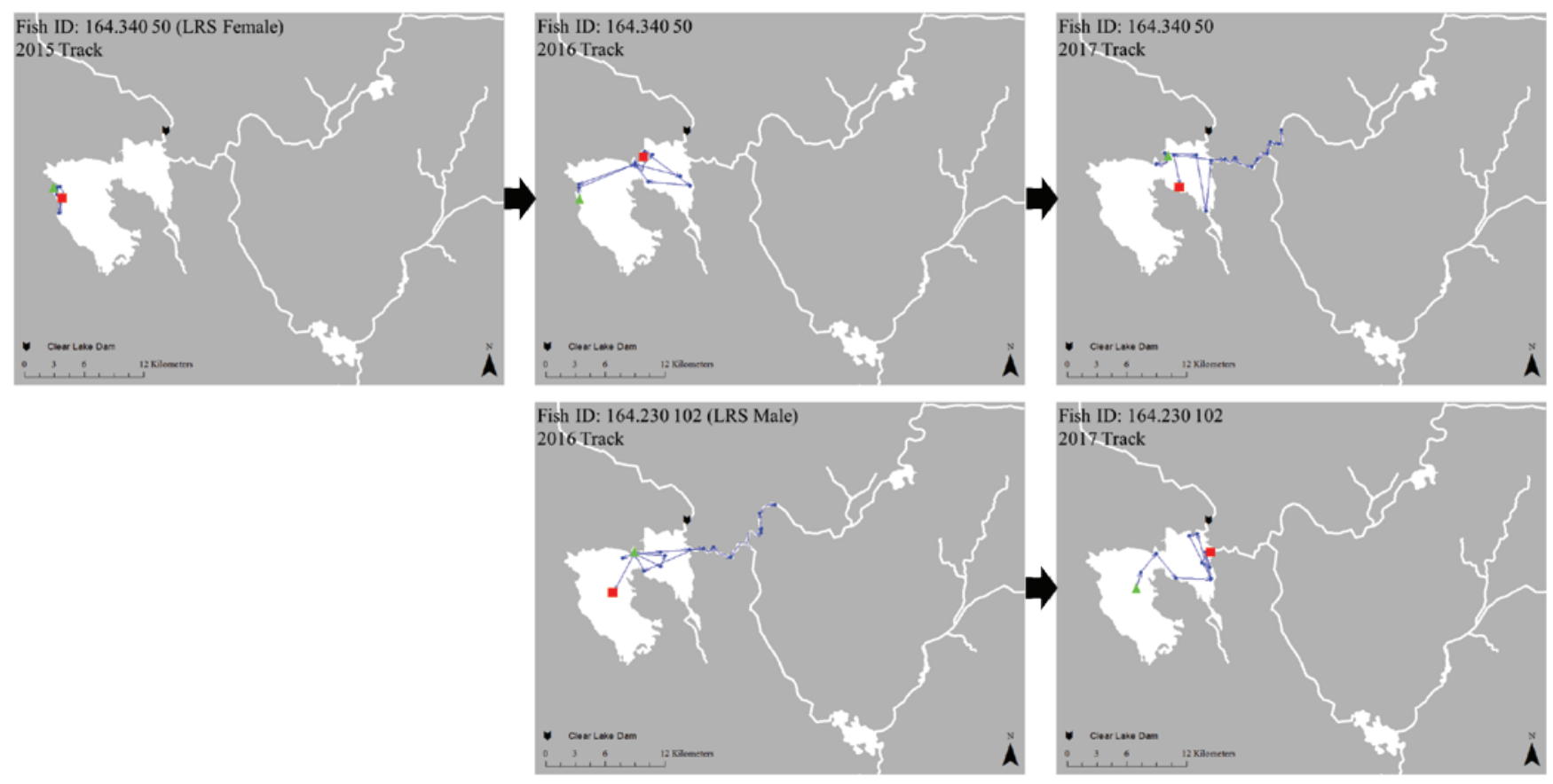

Figure 15. Individual movement and migration tracks of two radio-tagged Lost River suckers (LRS), one female (164.340 50) and one male (164.230 102), by year, in Clear Lake watershed, California. Green triangles indicate first location in a given year; blue circles and lines indicate movements and locations throughout a given year; red squares indicate final location in a given year. Animated tracks are available online (https://doi.org/10.3133/ofr20211061).

2017, the female LRS had pre-spawning movements in the east lobe of Clear Lake (January 6-February 23), migrated to Upper Willow Creek (March 13-March 24), and returned to the east lobe of Clear Lake after spawning (May 8-May 24). The last location was in Clear Lake on May 24, 2017, at a time estimated to be at the end of the transmitter's battery life. The LRS male (164.230 102), tagged in the autumn of 2015 , had pre-spawning movements in Clear Lake (January 20February 9, 2016), migrated to Upper Willow Creek (March 7-April 6, 2016), and returned to Clear Lake for the remainder of 2016 (April 21-September 23). This same LRS male was resident in Clear Lake in 2017 (January 14-June 14) and moved from the west lobe to the east lobe. Animated tracks of the two aforementioned LRS (164.340 50 and 164.230102 ) along with tracks of additional LRS and SNS are available online (https://doi.org/10.3133/ofr20211061).

Locations of two SNS, one female and male, were plotted as movement and migration tracks by year (fig. 16). The SNS female (164.340 42), tagged in the autumn of 2014, showed a movement pattern from February 11 to November 13, 2015, that indicated residency behavior in the west lobe of Clear Lake. In 2016, this same SNS female migrated out of Clear Lake to a spawning location in Boles Meadow. The last location in Clear Lake was on January 27, 2016, with subsequent locations in Lower Willow/Boles Creeks and Boles Meadow during February 24-April 21, 2016. The estimated mortality for this individual occurred on April 21, 2016, in Boles Meadow. The Boles Meadow head gates closed on April 15, 2016. The SNS male (164.290 120), tagged in the autumn of 2015, was a migrant in both 2016 and 2017. In 2016, this SNS male had pre-spawning movements in Clear Lake (January 20-February 9), a spawning migration into Lower Willow/Boles Creek (February 12-March 16), and postspawning movements within Clear Lake for the remainder of 2016 (April 4-November 2). In 2017, this same SNS male had pre-spawning movements in the east lobe of Clear Lake (January 14-March 13) and a spawning migration to Willow/ Boles Creek during March 28-June 14. The estimated mortality for this SNS male occurred during May 8-May 24, 2017, in Boles Creek, downstream from the Boles Meadow head gates, which were closed on April 17, 2017. The SNS male was located in the same area in mid-Boles Creek in 2016 and 2017 on multiple surveys. Animated tracks of the two aforementioned SNS (164.340 42 and 164.290 120) along with tracks of additional LRS and SNS are available online (https://doi.org/10.3133/ofr20211061).

\section{Choice of Spawning Tributary}

During the spawning seasons of 2011, 2016, and 2017, a total of 32 LRS and 44 SNS were detected upstream from the confluence of Willow and Boles Creeks. All 3 years provided access to spawning tributaries. LRS strongly favored Upper Willow Creek as a spawning tributary compared to Boles Creek, whereas SNS selected the two areas more equally (fig. 17). No LRS or SNS were detected in both Boles Creek and Upper Willow Creek during the same spawning season. 

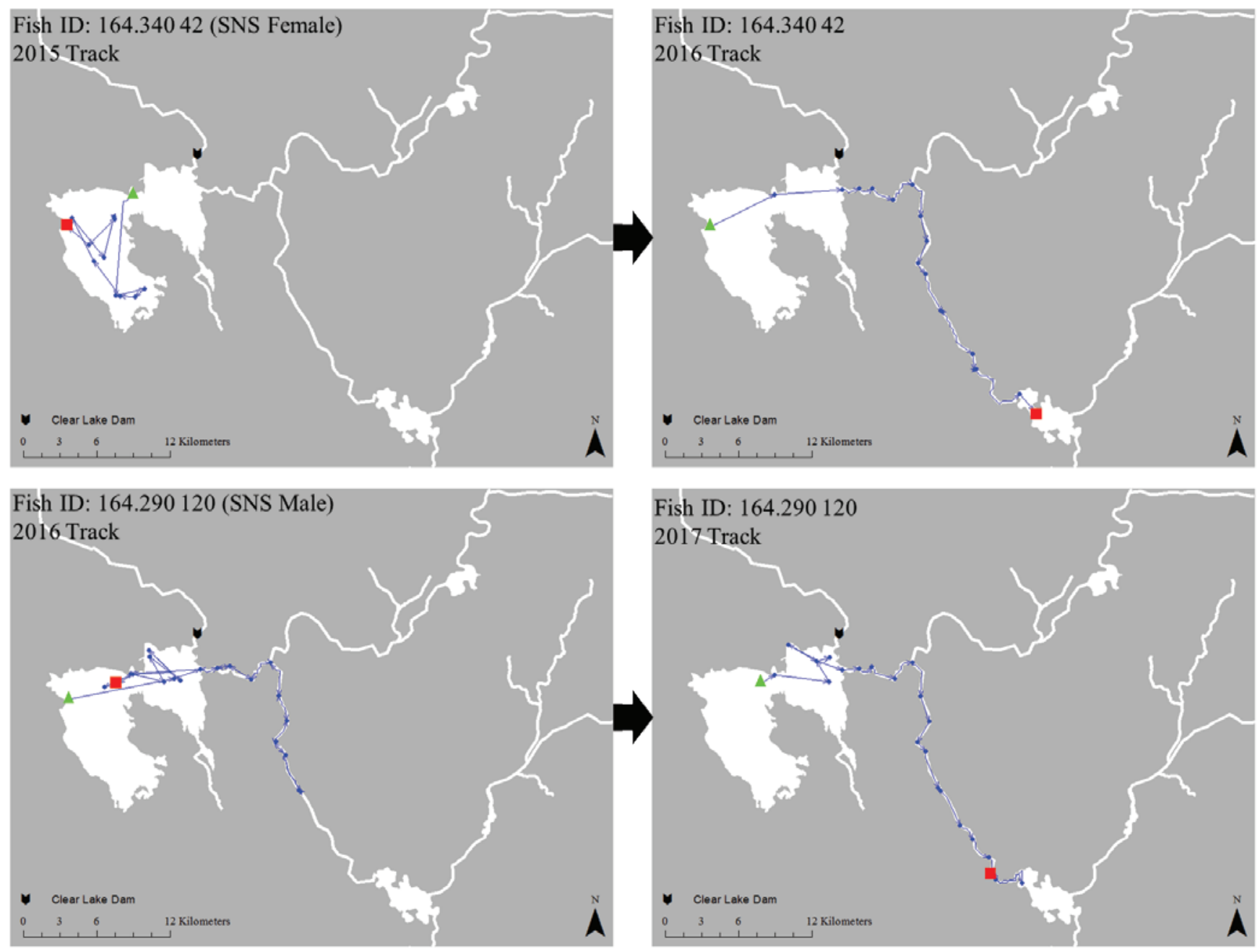

Figure 16. Individual movement and migration tracks of two radio-tagged shortnose suckers (SNS), one female (164.340 42) and one male (164.290 120), by year, in Clear Lake watershed, California. Green triangles indicate first location in a given year; blue circles and lines indicate movements and locations throughout a given year; red squares indicate final location in a given year. Animated tracks are available online (https://doi.org/10.3133/ofr20211061). 

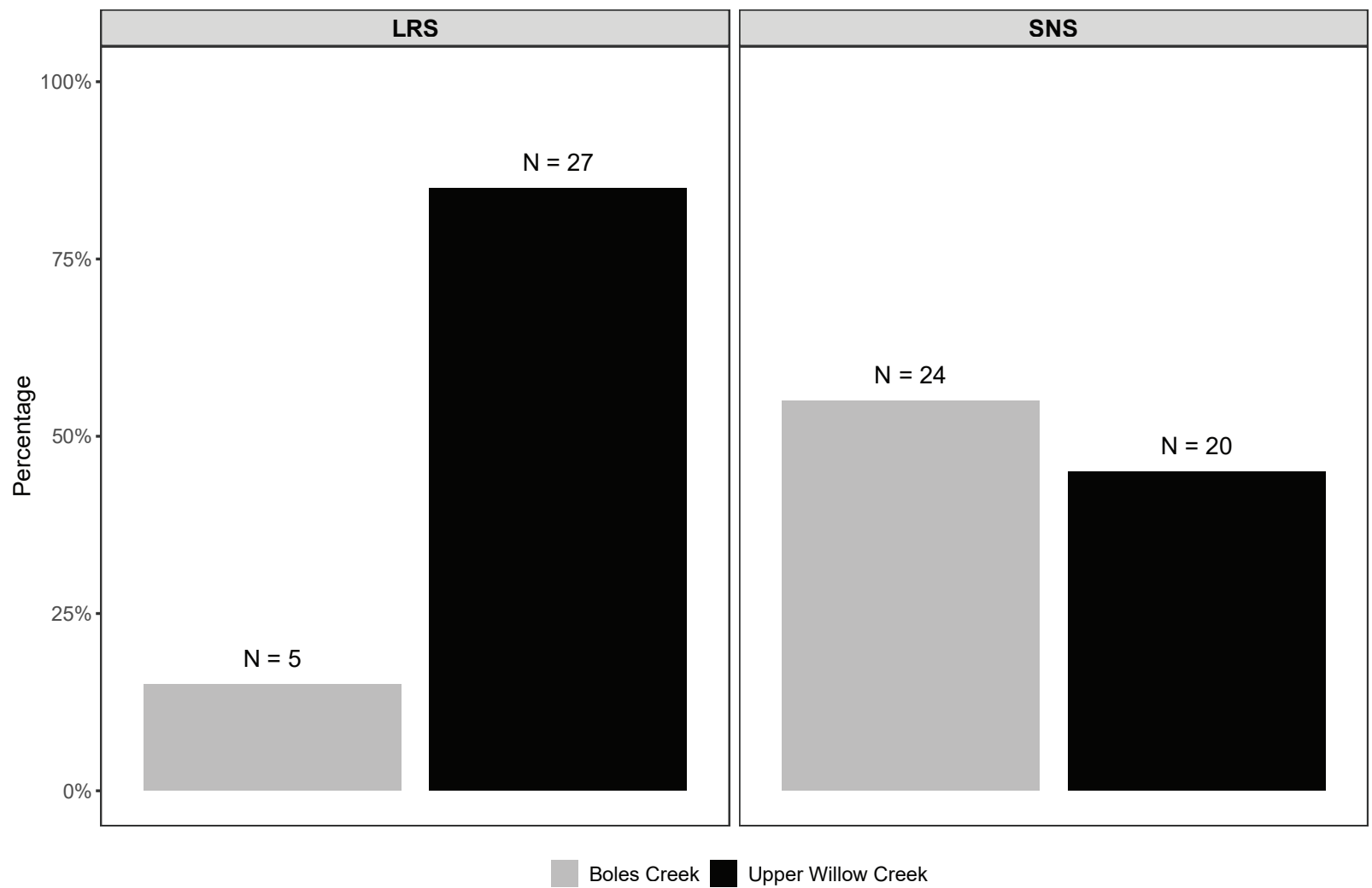

Figure 17. Percentage of radio-tagged Lost River and shortnose suckers (LRS and SNS) that were detected in Boles Creek or Upper Willow Creek, upstream from their confluence, in the Clear Lake watershed, California, during the spawning seasons of 2011, 2016, and 2017. [N, total number of individuals and their choice of spawning tributary.]

\section{Percentage of Migrants and Residents}

During the spawning seasons of 2016 and 2017, the percentages of radio-tagged individuals that migrated or were resident varied between years (fig. 18). In 2016, most LRS (73 percent of females; 72 percent of males) and SNS (79 percent of females; 56 percent of males) migrated out of Clear Lake (fig. 18). The lake surface elevation during the spawning season ranged from 1378.3 to $1,379.5 \mathrm{~m}(4,522-4,526 \mathrm{ft})$. Fish residing in the dam channel were able to access Willow Creek in February of 2016, but fish in the main body of the lake could not access the creek until mid-March. Nonetheless, lake surface elevation was sufficient to provide access to spawning tributaries and most LRS and SNS migrated in 2016.

In 2017, most LRS (77 percent of females; 62 percent of males) and SNS (83 percent of females; 89 percent of males) migrated out of Clear Lake (fig. 18). A larger percentage of male SNS made a spawning migration compared to 2016. The lake surface elevation during the spawning season ranged from $1,379.2$ to $1,381.7 \mathrm{~m}(4,525-4,533 \mathrm{ft})$, which provided unimpeded access to spawning tributaries by early February in 2017.

Seventeen LRS ( 7 females; 10 males) and 12 SNS (8 females; 4 males) were monitored for both 2016 and 2017 spawning seasons when there was access to spawning tributaries. Because of small sample sizes (partly owing to mortalities, expelled transmitters, and unknown fates), we summarized the percentages of individuals that were residents, migrants, or a mix of migrant and resident across all individuals for each species and sex. None of the individuals of either species were resident in the reservoir during both spawning seasons. For LRS, 41 percent were migrants and 59 percent were both resident and migrant. For SNS, 67 percent were migrants and 33 percent were both resident and migrant. 


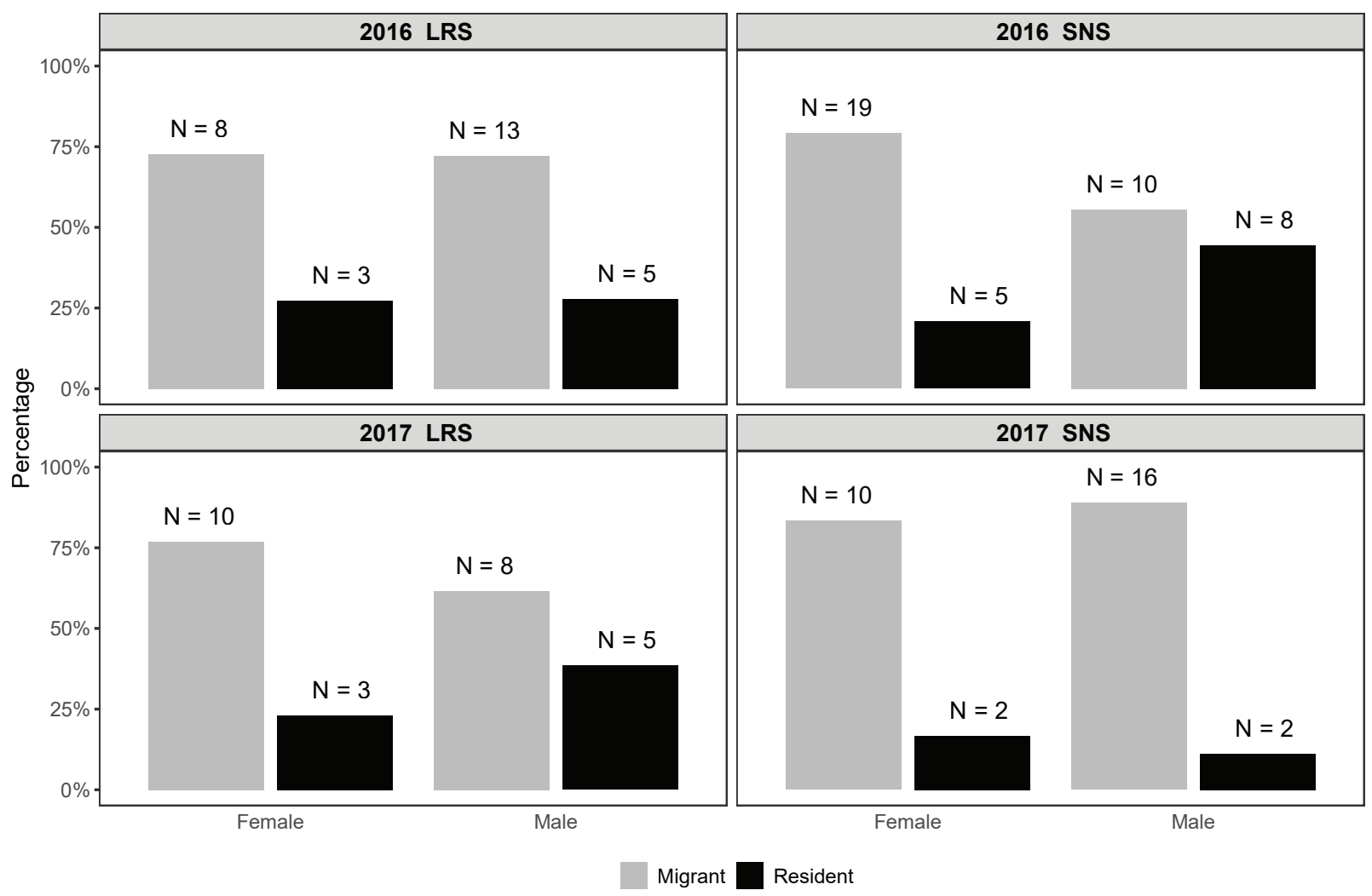

Figure 18. Percentage of radio-tagged Lost River and shortnose suckers (LRS and SNS) that were migrants from and residents of Clear Lake, California, during the spawning seasons of 2016 and 2017. [N, total number of individual migrants or residents.]

\section{Discussion}

This multi-year radio telemetry study expanded our understanding of the spatiotemporal distributions of populations of LRS and SNS in Clear Lake. We examined movements and migrations in three hydrologically variable water years during pre-spawning, spawning, and post-spawning time periods. Most of the radio-tagged suckers were encountered at least once following their release in the west lobe of Clear Lake, although mortalities of natural and unknown causes were the most common fate for each species and sex. The lack of spawning migrations by radio-tagged LRS and SNS in 2015 showed how lake surface elevation and access to Willow Creek continues to be a limiting factor in sucker recovery. In years when conditions permitted spawning migrations (2016 and 2017), most LRS and SNS of each sex migrated into the tributaries. LRS migrated primarily within the mainstem of Willow Creek, whereas SNS were observed in Willow, Boles,
Fourmile, Wildhorse, and Fletcher Creeks. SNS migrated farther and were observed in approximately 80 percent of their designated critical habitat in spawning tributaries. This contrasts with LRS that were observed in approximately 40 percent of their designated critical habitat in the spawning tributaries, as well as parts of Upper Willow Creek not designated as critical habitat. Although SNS maintain a more extensive spawning distribution, it may be costly for individuals that migrate late or make long migrations. For these individuals, water control structures and dams may impede post-spawning migrations back to Clear Lake. Mortalities of radio-tagged SNS in spawning tributaries raises concerns about water quality and flow modifications, susceptibility to avian predation, and availability of in-stream refuges for adults and juveniles following closure of head gates, particularly at Boles Meadow. The limited spawning distribution of LRS and the mortalities of SNS in the upper tributaries are of concern for the recovery of sucker populations in Clear Lake. 


\section{Radio Telemetry Methods}

Given the extent and remoteness of the Clear Lake watershed, aerial telemetry surveys provided the most efficient means of detecting radio-tagged suckers. Although aerial surveys were conducted as consistently as possible, some flights yielded more noise contacts than others. We could not determine the cause of high noise on some surveys that resulted in particularly poor data (for example, February 24, 2017). Surveys were conducted more frequently in the spring of each year to document spawning migrations, but poor weather sometimes prevented surveys from being conducted as frequently as desired. Combined with highly variable flows and temperatures in the spawning tributaries, some pre-spawning and spawning movements were missed. Spawning migrations in Willow Creek occurred when water temperatures were as low as $2-3{ }^{\circ} \mathrm{C}$, but specific temperature thresholds were not as evident compared to populations in Upper Klamath Lake that spawn in the Williamson River. In the Williamson River, migrations occur during rising water temperatures near or greater than 10 and $12{ }^{\circ} \mathrm{C}$ for LRS and SNS, respectively (Hewitt and others, 2012, 2014). The lack of clear temperature triggers for migrations out of Clear Lake created challenges in timing aerial surveys to capture the full extent of the spawning distribution. Installing several remote telemetry stations at key locations throughout the spawning tributaries (for example, Ellsworth and others, 2007; Ellsworth and VanderKooi, 2011) would supplement aerial survey data and potentially fill in data gaps. Possible remote sites include the Clear Lake Reservoir Road crossing of Boles Creek and the U.S. National Forest Road 48N70 crossing of Willow Creek. Nonetheless, the remoteness of these locations and common inclement weather in the spring would make maintenance of remote telemetry sites challenging.

We used a combination of radio telemetry and remote PIT tag detections to fill in data gaps, particularly during spawning. Radio telemetry confirmed that some PIT tag detections were missed by the Willow Creek antenna array, which is expected (Hewitt and others, 2021). Similarly, remote PIT tag detections in Willow Creek also confirmed that some radiotagged fish migrated in 2016 and 2017 but were not detected during scheduled telemetry flights. Missed detections of fish with transmitters can occur for various reasons. A radiotagged fish could certainly complete a spawning migration between scheduled telemetry flights. However, in a separate analysis that calculated duration of time spent upstream from the Willow Creek antenna array, we determined that data from radio telemetry in 2016 and 2017 corroborated most calculations of time spent upstream for the same fish based on PIT tag detections (USGS, unpub. data, 2018). This could be important in understanding more about the duration of spawning runs into Willow and Boles Creeks, of which little is known. Although sample sizes were small (15 LRS and 17 SNS), Perkins and Scoppettone (1996) observed that LRS and SNS spend as many as 16 days and 43 days, respectively, in Clear Lake spawning tributaries.

\section{Relocation Histories and Transmitter Recoveries}

Fates of radio-tagged individuals were determined based on the best available data using a combination of PIT tag and telemetry detections. Although why some radio tags were never detected following their release is unclear, these fish were possibly mortalities, and their tags could have been deposited outside the survey area. Another possibility is a failed radio tag. Although all the transmitters were field-tested for power and range prior to deployment, another telemetry study in Upper Klamath Lake documented 8 percent of tags malfunctioning from unknown causes (Ellsworth and others, 2007). One transmitter, deployed in 2014, was detected in 2015 and 2017 but not in 2016. An error could have occurred related to the programming that turned off the tag in December and re-activated it in January.

Causes of mortalities are unknown with the exception of transmitters that were recovered on avian colonies in 2015 or in Fourmile/Wildhorse creeks in 2017. However, some transmitters were recovered near the surgery site and it is reasonable to conclude that some fish suffered complications from the transmitter implantation process. Our inferences about movement and spawning migrations were unbiased by these effects because we implanted transmitters in autumn and only monitored transmitters known to be active the following spring. Some transmitters were expelled by the fish as much as 2 years after implantation. Causes of fish prematurely expelling tags are unknown, but infections from transmitters with external trailing antennas that connect the peritoneal cavity with the external environment have been linked to tag expulsions (O'Connor and others, 2009). One possible way to avoid mortalities or tag expulsions would be to use tags that have an internal loop antenna like those that have been used in common carp (Cyprinus carpio; O'Connor and others, 2009) and razorback sucker (Xyrauchen texanus; Modde and Irving, 1998). All radio transmitters in this study had external antennas because of their better range for aerial surveys in an area known occasionally to have high noise interference. Suckers from the Williamson River fitted with external radio tags had a 6 percent tag loss rate (Ellsworth and others, 2007; Ellsworth and VanderKooi, 2011), which was similar to the overall tag loss we observed from this study using internal implant transmitters (8.5 percent). 
Unknown fates also can result from deposition outside the survey area. Several surveys each year included time spent over islands outside of Clear Lake in the Klamath National Wildlife Refuge Complex where colonial waterbirds have been known to breed or loaf. Transmitters from Clear Lake were never detected at these locations, corroborating evidence that colonial waterbirds from breeding colonies outside of Clear Lake rarely commute to Clear Lake to forage (Evans and others, 2016). Given that radio tags from our study were only recovered on waterbird colonies in 2015, this further corroborates findings by Evans and others (2016) that effects of avian predation vary by year. Lower lake surface elevations in 2015 concentrated suckers in the west lobe or exposed suckers trapped in the east lobe, likely making suckers more susceptible to avian predation. The east lobe can vary in depth by more than $3 \mathrm{~m}$ among and within years and almost completely dried up in 2015 with a lake surface elevation at $1,377.7 \mathrm{~m}$ $(4,520 \mathrm{ft})$. Irrigation withdrawals in Upper Klamath Lake have been suspected to limit the amount of refuge habitat for suckers to avoid avian predation (Banish and others, 2009), and withdrawals from Clear Lake in dry years that decrease lake surface elevation may increase avian predation as well (Hostetter and others, 2012; Evans and others, 2016).

\section{Seasonal Spatial and Temporal Distribution}

Radio telemetry expanded our understanding of spatial and temporal distribution of suckers beyond what can be inferred from detections at non-directional PIT tag detection systems in Clear Lake and Willow Creek. Although detections at remote PIT tag antenna arrays provide important information about spawning migration timing and magnitude, telemetry provides more complete information about migrations during spawning and movements during other times of the year. Hewitt and Hayes (2013) suspected that nearly all suckers return to the west lobe at some point in the summer or autumn as lake surface elevations decrease. We observed LRS and SNS in both the east and west lobes during pre-spawning and post-spawning time periods when lake surface elevations peaked at 4,526 ft in 2016 and 4,533 ft in 2017. Access to both lobes of Clear Lake may be important during post-spawning periods to enable suckers to access deep-water refuge habitat in the west lobe that could reduce the risk of avian predation (Evans and others, 2016). Although PIT tag data provided additional information about fish with transmitters, telemetry detections illustrated several, species-specific patterns that would not have been possible using PIT tag data alone.

Species-specific patterns in spatial distribution have been described in previous studies of LRS and SNS populations in Upper Klamath Lake. We found evidence that spatial and temporal distributions of Endangered Species Act-listed suckers in Clear Lake were more dynamic in all time periods (pre-spawning, spawning, and post-spawning) than previously thought. One pattern we observed was an aggregation of LRS, predominantly males, in the east lobe near the Willow Creek mouth in a low-water year such as 2015. Aggregations near river mouths are common among other long-lived, potamodromous fish such as common carp (Chizinski and others, 2016) and Sacramento sucker (C. occidentalis; Moyle, 2002) prior to spawning. LRS have been known to migrate in Willow Creek prior to SNS (Perkins and Scoppettone, 1996), although migration timing for both species in recent years has been similar. Pre-spawning aggregations observed in Clear Lake may be similar to behaviors of river-spawning subpopulations of LRS and SNS that are found in pre-spawn staging areas in Upper Klamath Lake (Hewitt and others, 2017). Migrations of river-spawning subpopulations of LRS and SNS in Upper Klamath Lake are triggered by increasing water temperatures that are greater than $10{ }^{\circ} \mathrm{C}$ for LRS and $12{ }^{\circ} \mathrm{C}$ for SNS (Hewitt and others, 2014). These species-specific temperature thresholds provide some reproductive isolation in some years. Migratory behavior of Clear Lake suckers does not seem to provide such reproductive isolation.

A second pattern we observed was that SNS in Clear Lake seem to have a life-history strategy in which some individuals migrate farther than LRS in the spawning tributaries. This finding corroborates previous studies also reporting that SNS occupied a wider distribution than LRS in the tributaries to Clear Lake (Buettner and Scoppettone, 1991; Moyle, 2002; USGS unpub. data, 2011). However, this contrasts with riverspawning populations in Upper Klamath Lake in which LRS are known to migrate farther than SNS (NRC 2004; Ellsworth and VanderKooi, 2011; Martin and others, 2013). It is unclear why SNS migrate as far as $46 \mathrm{~km}$ in Boles Creek (Moyle, 2002) and farther than LRS in the Clear Lake system, but genetic introgression from Klamath largescale sucker is one possibility (Smith and others, 2020).

A third pattern we observed was that LRS appear to prefer and presumably spawn in Upper Willow Creek compared to Boles Creek, while avoiding small tributaries such as Wildhorse and Fourmile Creeks. LRS may require spawning habitat or flow conditions that are not available in the upper tributaries of Clear Lake. However, Buettner and Scoppettone (1991) observed LRS from Clear Lake as far upstream as Avanzino Reservoir, thus using an extensive reach of Upper Boles Creek to presumably spawn.

\section{Individual Migratory and Residency Behavior}

Potamodromous fish populations have been known to be composed of individuals that change their migratory or residency status over time (Banet, 2016; Prechtel and others, 2018). For radio-tagged suckers that were monitored in both 2016 and 2017, some LRS and SNS showed residency in one year and migratory behavior in another year. However, due to the small number of individuals that were monitored for two complete spawning seasons, we could not draw populationlevel conclusions about the influence of sex on migratory and residency behavior for the two species. Given the large number of suckers that are PIT-tagged in Clear Lake, further investigation of sex-specific migratory behavior could be explored using PIT tag detections at the Willow Creek array. 
Spawning populations of LRS and SNS in Clear Lake may have developed an adaptive life-history strategy to migrate whenever lake surface elevations provide access to spawning tributaries and inflows are sufficient. Given the inconsistent access to spawning tributaries in Clear Lake, previous studies have noted the possibility of spawning occurring in other locations in Clear Lake (Buettner and Scoppettone, 1991; Barry and others, 2009; Burdick and Rasmussen, 2013) or skipped spawning (Perkins and Scoppettone, 1996; Barry and others, 2009; Hewitt and Hayes, 2013). Skipped spawning has been noted in other sucker species such as white sucker (C. commersoni) and longnose sucker (C. catostomus; Dion and others, 1994).

\section{Flow Modifications and Barriers to Migration}

Population-level patterns provide context for broad spatial and temporal patterns among species, but individual movements and migrations show fine-scale, interannual patterns that identify individual mortalities. Specifically, we were interested in why, when, and where mortalities occurred in designated critical habitat during spawning. This is of particular importance to habitat use in upper tributaries where operation of water control structures, both Federal and private, corresponds with mortalities of radio-tagged SNS in 2016 and 2017. We found no evidence that supports survival of radio-tagged suckers in tributaries during summer or throughout the winter. Although radio-tagged LRS also were observed migrating in tributaries, all returned to Clear Lake after spawning, and their migration distance was less extensive than that of SNS. In this report section, we address three types of barriers that influence flow and may act as barriers to sucker movements in critical spawning habitat: (1) USFS head gates at Boles Meadow and Weed Valley, (2) privately operated dams at Fletcher and Avanzino Reservoirs, and (3) earthen dams throughout the watershed of Willow and Boles Creeks.

Closure of two USFS-operated head gates was consistent in 2016 and 2017 and coincides with mortalities of SNS located upstream and downstream from Boles Meadow in both years. Although exact dates of mortalities in 2016 could not be determined, we identified a time frame (April 4-May 9, 2016) in which they were most likely to have occurred. This time frame coincides with the closure of the Boles Meadow head gates on April 15, 2016. We also found evidence that SNS were migrating upstream in Boles Creek after the head gates at Boles Meadow were closed, with a mortality 6 days after the closure in 2016 and immediately downstream from the head gates. Thus, presumably late-migrating SNS had not reached their final spawning location prior to the closure of the head gates. Although there were fewer mortalities in 2017 compared to 2016, perhaps owing to higher flows that favored postspawning migrations back to Clear Lake, we observed one SNS mortality in Boles Meadow in May following the closure of the head gates on April 17, 2017. The USFS-operated head gates at Weed Valley were closed in mid-May. We observed no mortalities of radio-tagged suckers in the mainstem of Willow Creek in 2016 and 2017, and the later closure of the Weed Valley head gates may provide more favorable conditions for out-migrating LRS and SNS spawning in Upper Willow Creek. Closure of head gates at the same time each year may unintentionally strand out-migrating and late-migrating fish, suggesting a need for more adaptive management in a system where annual variation in water availability and timing can be extreme.

Two other reservoirs, Fletcher and Avanzino, are both privately owned and operated along the mainstem of Fletcher Creek. Fletcher Creek is an extensive and intermittent tributary to Boles Creek and the only tributary with long reaches of private ownership (Buettner and Scoppettone, 1991). The specific dates of opening and closing of any head gates associated with these private reservoirs is unknown. However, any modification of streamflow at Fletcher Reservoir may have been associated with one radio-tagged, SNS female in lower Fletcher Reservoir that had an estimated mortality on April 4, 2016. Although we do not speculate on the operation of these privately owned dams, more specifics on their operation are needed and whether their operation is consistent with the operation of head gates owned and operated by the USFS. Given that spawning and rearing habitat upstream from Fletcher Reservoir is a mix of private and Federal land, management of critical habitat in these upper tributaries is more complex.

Detailed information from telemetry data allowed us to document how earthen dams within the Clear Lake watershed may serve as additional migratory barriers for spawning suckers. Burdick and Rasmussen (2013) acknowledged that numerous earthen dams in Willow and Boles Creeks may create barriers to migration. Buettner and Scoppettone (1991) reported more than 30 small reservoirs in the Clear Lake watershed, and most are still used today (J. Jayo, USFS, oral commun., 2018). However, in dry years such as 2014 and 2015, only about one-half of these reservoirs hold water. Most are created by man-made dams that serve as stock ponds for cattle, artificial wetlands for waterfowl, and evaporation basins for the Klamath Irrigation Project (Buettner and Scoppettone, 1991; Moyle, 2002). Although we directed most of our attention for migratory barriers at the head gates of Boles Meadow, the potential barriers that small reservoirs pose for adult suckers are largely unknown. However, mortalities of adult SNS observed in the Wildhorse and Fourmile drainage basins may provide indication of barriers in critical habitat for adult SNS in small spawning tributaries. In Fourmile Creek, there are at least eight small reservoirs upstream from the confluence with Willow Creek, and all hold at least some water even in dry years. Although the exact timing of the mortalities in the Fourmile/Wildhorse drainage each year is unknown, we presume they occurred in late spring in 2016 and 2017 (MayJune) as flows were receding. There may have been more radio-tagged individuals that used Fourmile and Wildhorse Creeks as surveys did not initially target the Fourmile and Wildhorse drainages until weak signals near the confluence with Willow Creek were detected in 2017. Future studies 
could investigate whether mortalities in small tributaries are associated with earthen dams and water control structures. There are no head gates on the reservoirs within Wildhorse and Fourmile Creeks, but the dams may create pool habitat conditions similar to those observed behind and downstream from head gate structures once they are closed in spring. Water quality in, and the importance of, these small tributaries and reservoirs as spawning and rearing habitat are still being investigated.

\section{Avian Predation Concerns}

Avian predation is a known limiting factor in the recovery of populations of adult LRS and SNS in Clear Lake (Evans and others, 2016). Evans and others (2016) recommended additional research into whether loss of deep-water refugia and limited access to spawning tributaries are associated with increased susceptibility of suckers to avian predation in the Upper Klamath Basin. Avian predation rates on adult suckers by American white pelicans (Pelecanus erythrorhynchos; AWPE) and double-crested cormorants (Phalacrocorax auritus; DCCO) nesting at mixed-species colonies in Clear Lake have been higher than predation rates on adult suckers in Upper Klamath Lake. Although the current study confirmed avian predation on suckers during low lake surface elevations in Clear Lake in 2015, avian predation also has been noted in a previous telemetry study during higher lake surface elevations in 2011. Two radio-tagged adult SNS were last located in Boles Creek on May 24, 2011, before being located on an AWPE colony in the east lobe of Clear Lake in the following three surveys (USGS, unpub. data, 2011). These two individuals were detected ascending Willow Creek in March, presumably on their upstream migration that coincided with high inflows. One of these individuals was last detected in Boles Meadow and the other in Boles Creek downstream from the head gates. If the Boles Meadow head gates were closed in mid-April of 2011 (like operations in 2016 and 2017), outmigration from Boles Meadow may not have been possible. The downstream reaches of Boles Creek were later reported as isolated pools and reservoirs in June and July (USGS, unpub. data, 2011). Both situations could have increased susceptibility of suckers to avian predation as water levels in tributaries receded and refuge habitat was limited. However, it is unknown whether these individuals were moribund, injured, or weaker after spawning, all of which could increase vulnerability of suckers to predation (Evans and others, 2016). Hostetter and others (2012) reported that injured or diseased fish were more susceptible to predation by DCCO compared to healthy fish. Despite low counts of AWPE and DCCO in 2011 (205 total individuals) and subsequent colony failure, minimum avian predation rates on SNS were still relatively high in Clear Lake (2.1 percent; Evans and others, 2016). Avian predators likely take advantage of the variability in lake surface elevations in dry years that prevent access to spawning tributaries, and receding flows in spawning tributaries in wet years that provide access to small spawning tributaries. These attributes and the operation of head gates in spawning tributaries may increase the susceptibility of suckers to avian predation in Clear Lake compared to populations in Upper Klamath Lake.

Other studies also have linked predation by colonial waterbirds to seasonal sources of prey that include spawning migrants, emigrating juveniles, and impeded access in tributaries created by dams, impoundments, or changes to streamflow (Collis and others, 2002; Dalton and others, 2009; Scoppettone and others, 2014; Budy and others, 2016). It is unclear whether water quality in the tributaries to Clear Lake compromise the condition of suckers. Allouche and Gaudin (2001) noted that juvenile chub (Leuciscus cephalus) exposed to avian predation foraged less, sheltered, and grew slower compared to chub that foraged more in riffles without the threat of avian predators or had higher stream velocities that provided cover. Water-quality sampling in the tributaries to Clear Lake during the summer will provide more information on the in-stream conditions after the closure of the head gates. Suckers in upper tributaries in late summer may be restricted to refuge habitat in isolated pools and reservoirs that could increase predation risk by piscivorous waterbirds. Dozens of AWPE were observed in Boles Meadow during the closure of the head gates in spring 2018 (J. Jayo, USFS, oral commun., 2018). However, isolated pool habitats with appropriate cover (overhanging banks, larger rocks, woody debris, and aquatic rooted vegetation) have the potential to serve as drought refuges and have been effective for another western sucker species, the Modoc sucker (C. microps; Moyle, 2002; USFWS, 2015). Stream habitat and hydrologic conditions for Modoc suckers likely are similar to those of spawning tributaries to Clear Lake. Although Modoc suckers are known to be pool dwellers, future studies could investigate how the refuge pool habitat of Modoc sucker compares to pool habitat conditions in the Clear Lake watershed. Improvements in refuge habitat and restoration of natural streamflow in tributaries have the potential to decrease the risk of avian predation.

\section{Adaptations and Recovery Limitations}

The recovery of sucker populations in Clear Lake is threatened by the effects of climate change, which include decreased snowfall, earlier snowmelt, and earlier peak spring runoff that all contribute to reduced water quantity, spread of disease and parasites, and increase in invasive and nonnative species (NMFS and USFWS, 2013). The isolation of spawning LRS and SNS in Clear Lake may have forced adaptations to small spawning tributaries with inconsistent access in combination with the possibility of skipped spawning. Although most radio-tagged suckers migrated to spawning tributaries when lake surface elevations and inflows provided access, we also observed radio-tagged suckers remaining resident in Clear Lake during spawning. This contrasts with river-spawning populations in Upper Klamath Lake that have reliable access to larger spawning tributaries each year. Current water management of Clear Lake relies heavily on inflows from small tributaries to replenish lake surface elevations and seems to have influenced the spawning behavior of LRS and SNS. 
The variation in migration extent and mortalities among individuals and between species provides evidence that migration (spawning and non-spawning) is complex, and management of critical habitat in spawning tributaries is equally complex (Cooke and others, 2008; Thurow, 2016). However, future research that examines habitat quality in the lower and upper spawning tributaries may identify additional factors limiting the recovery of Clear Lake sucker populations. The restoration of Sun Creek (Klamath County, Oregon) for bull trout (Salvelinus confluentus) and redband trout (Oncorhynchus mykiss newberrii) provides an example of grazing co-existing with improved fish habitat and connectivity for potamodromous species (Buktenica and others, 2018). Riparian fencing, landowner outreach, and improved grazing management also have been contributing factors in the recovery and delisting of the Modoc sucker that has critical habitat within Modoc National Forest and private lands (USFWS, 2015). Although some of the stream habitat upstream from Clear Lake in Modoc National Forest has riparian fencing to exclude cattle (Moyle, 2002), the most protected spawning habitat occurs in downstream reaches and canyons of Boles and Willow Creeks that also include the fewest number of dams. Future studies could identify in-stream refuges throughout the critical habitat in the tributaries that may be important during and beyond the spawning season.

\section{Conclusions}

Future management of critical habitat for spawning populations of Lost River suckers (LRS; Deltistes luxatus) and shortnose suckers (SNS; Chasmistes brevirostris) in Clear Lake, northern California, requires a complete understanding of the possible movements, migrations, and fates of suckers that may be associated with lake surface elevation, Willow Creek inflows, and flow modifications in tributaries during and immediately following the spawning season. This information is important to managers, particularly in a system known for high interannual variation in water availability. When access to spawning tributaries is available, the influence of small earthen dams seems to have an effect similar to closure of the head gates as flows recede. Critical habitat has been designated for parts of upstream tributaries for spawning populations of LRS and SNS in Clear Lake. We determined that most LRS avoided critical habitat in Boles Creek from the confluence with Willow Creek to Avanzino Reservoir. Although we observed LRS using the mainstem of Willow Creek in their critical habitat, LRS also were found in Upper Willow Creek (upstream from the confluence with Boles Creek), which is not currently designated as critical habitat. One concern for managers may be understanding why LRS critical habitat in Boles Creek may be less suitable for spawning. Flow modifications also affect the ability of post-spawning adults to return to Clear Lake.

\section{Acknowledgments}

We thank Lisa Gee for study design and planning assistance, for serving as surgeon for transmitter implantations over the duration of the study, and for reviewing the manuscript. We thank Barbara Martin and Matt Sholtis for their review and comments. We also thank Uwe Britsch and Bob Skinner of Skinner Aviation for conducting the aerial surveys.

\section{References Cited}

Allouche, S., and Gaudin, P., 2001, Effects of avian predation threat, water flow and cover on growth and habitat use by chub, Leuciscus cephalus, in an experimental stream: Oikos, v. 94 , no. 3, p. 481-492, https://doi.org/10.1034/j.16000706.2001.940310.x.

Banet, N.V., 2016, Partial migration, homing, diel activity, and distribution of adult common carp across a large, model watershed in the North American Midwest: St. Paul, Minnesota, University of Minnesota, M.S. thesis, 139 p.

Banish, N.P., Adams, B.J., Shively, R.S., Mazur, M.M., Beauchamp, D.A., and Wood, T.M., 2009, Distribution and habitat associations of radio-tagged adult Lost River suckers and shortnose suckers in Upper Klamath Lake, Oregon: Transactions of the American Fisheries Society, v. 138, no. 1, p. 153-168, https://doi.org/10.1577/T07-252.1.

Barry, P.M., Janney, E.C., Hewitt, D.A., Hayes, B.S., and Scott, A.C., 2009, Population dynamics of adult Lost River (Deltistes luxatus) and shortnose (Chasmistes brevirostris) suckers in Clear Lake Reservoir, California, 2006-08: U.S. Geological Survey Open-File Report 2009-1109, 18 p., https://doi.org/10.3133/ofr20091109.

Budy, P., Chapman, K., and Thiede, G.P., 2016, Pelican predation effects on the fish community in Strawberry Reservoir: Annual Performance Report to Utah Division of Wildlife Resources, Utah Cooperative Fish and Wildlife Research Unit, $29 \mathrm{p}$.

Buettner, M.E., and Scoppettone, G.G., 1990, Life history and status of catostomids in Upper Klamath Lake, Oregon: Reno, Nevada, National Fisheries Research Center, 108 p.

Buettner, M.E., and Scoppettone, G.G., 1991, Distribution and information on the taxonomic status of the shortnose sucker (Chasmistes brevirostris) and Lost River sucker (Deltistes luxatus) in the Klamath River Basin, California: Completion Report to California Department of Fish and Game Under Contract FG-8304, Seattle National Fishery Research Center, Reno Substation, 34 p. 
Buktenica, M.W., Hering, D.K., Scott, N., Lambert, C., McKee, J., Maletis, E., Pellissier, J., Tinniswood, W., and Banish, N., 2018, A long-term watershed-scale partnership to restore bull trout across Federal, State, private, and historic Tribal land near Crater Lake National Park, Oregon: Fisheries (Bethesda, Md.), v. 43, no. 4, p. 183-193, https://doi.org/10.1002/fsh.10047.

Burdick, S.M., Hewitt, D.A., Rasmussen, J.E., Hayes, B.S., Janney, E.C., and Harris, A.C., 2015, Effects of lake surface elevation on shoreline-spawning Lost River suckers: North American Journal of Fisheries Management, v. 35, no. 3, p. 478-490, https://doi.org/10.1080/02755947.20 15.1017124 .

Burdick, S.M., and Martin, B.A., 2017, Inter-annual variability in apparent relative production, survival, and growth of juvenile Lost River and shortnose suckers in Upper Klamath Lake, Oregon 2001-15: U.S. Geological Survey Open-File Report 2017-1069, 55 p. [Also available at https://doi.org/ 10.3133/ofr20171069.]

Burdick, S.M., Ostberg, C.O., and Hoy, M.S., 2018, Juvenile Lost River and shortnose sucker year class strength, survival, and growth in Upper Klamath Lake, Oregon, and Clear Lake Reservoir, California—2016 monitoring report: U.S. Geological Survey Open-File Report 2018-1066, 43 p. [Also available at https://doi.org/10.3133/ofr20181066.]

Burdick, S.M., and Rasmussen, J.E., 2013, Age and condition of juvenile catostomids in Clear Lake Reservoir, California: U.S. Geological Survey Open-File Report 2013-1188, 20 p. https://doi.org/10.3133/ofr20131188.

Bureau of Reclamation (Reclamation), 2008, Permanent operating agreement for Weed Valley-Between the United States Department of the Interior, Bureau of Reclamation's Klamath Basin Area Office and the United States Department of Agriculture, Forest Service, Modoc National Forest—Letter dated February 22, 2008: U.S. Bureau of Reclamation, Klamath Basin Area Office, 1 p.

Bureau of Reclamation and U.S. Forest Service (Reclamation and USFS), 1984, Boles Meadows Dam operating agreement: U.S. Bureau of Reclamation, Klamath Basin Area Office and U.S. Forest Service, Modoc National Forest, 8 p.

Chizinski, C.J., Bajer, P.G., Headrick, M.E., and Sorensen, P.W., 2016, Different migratory strategies of invasive common carp and native northern pike in the American Midwest suggest an opportunity for selective management strategies: North American Journal of Fisheries Management, v. 36, no. 4, p. 769-779, https://doi.org/10.1080/02755947.20 16.1167141 .
Collis, K., Roby, D.D., Craig, D.P., Adamany, S., Adkins, J.Y., and Lyons, D.E., 2002, Colony size and diet composition of piscivorous waterbirds on the lower Columbia RiverImplications for losses of juvenile salmonids to avian predation: Transactions of the American Fisheries Society, v. 131, no. 3, p. 537-550, https://doi.org/10.1577/15488659(2002)131<0537:CSADCO>2.0.CO;2.

Cooke, S.J., Hinch, S.J., Farrell, A.P., Patterson, D.A., MillerSaunders, K., Welch, D.W., Donaldson, M.R., Hanson, K.C., Crossin, G.T., Mathes, M.T., Lotto, A.G., Hruska, K.A., Olsson, I.C., Wagner, G.N., Thomson, R., Hourston, R., English, K.K., Larsson, S., Shrimpton, J.M., and Van der Kraak, G., 2008, Developing a mechanistic understanding of fish migrations by linking telemetry with physiology, behavior, genomics and experimental biology-An interdisciplinary case study on adult Fraser River sockeye salmon: Fisheries (Bethesda, Md.), v. 33, no. 7, p. 321-339, https://doi.org/10.1577/1548-8446-33.7.321.

Cooperman, M.S., and Markle, D.F., 2003, Rapid outmigration of Lost River and shortnose suckers from in-river spawning beds to in-lake rearing grounds: Transactions of the American Fisheries Society, v. 132, no. 6, p. 1138-1153, https://doi.org/10.1577/T02-130.

Dalton, C.M., Ellis, D., and Post, D.M., 2009, The impact of double-crested cormorant (Phalacrocorax auratus) predation on anadromous alewife (Alosa pseudoharengus) in south-central Connecticut, USA: Canadian Journal of Fisheries and Aquatic Sciences, v. 66, no. 2, p. 177-186, https://doi.org/10.1139/F08-198.

Dingle, H., and Drake, A., 2007, What is migration?: Bioscience, v. 57, no. 2, p. 113-121, https://doi.org/ 10.1641/B570206.

Dion, R., Richardson, M., Roy, L., and Whoriskey, F.G., 1994, Spawning patterns and interspecific matings of sympatric white (Catostomus commersoni) and longnose (C. catostomus) suckers from the Gouin reservoir system, Quebec: Canadian Journal of Zoology, v. 72, no. 2, p. 195-200, https://doi.org/10.1139/z94-026.

Dowling, T.E., Markle, D.F., Tranah, G.J., Carson, E.W., Wagman, D.W., and May, B.P., 2016, Introgressive hybridization and the evolution of lake-adapted catostomid fishes: PLoS ONE, v. 11, 27 p. [Also available at https://doi.org/ 10.1371/journal.pone.0149884.]

Ellsworth, C.M., Luton, C.D., Tyler, T.J., VanderKooi, S.P., and Shively, R.S., 2007, Spawning migration movements of Klamath largescale, Lost River, and shortnose suckers in the Williamson and Sprague Rivers, Oregon, prior to the removal of Chiloquin Dam: U.S. Geological Survey Annual Report 2006 to U.S. Bureau of Reclamation and U.S. Fish and Wildlife Service, $51 \mathrm{p}$. 
Ellsworth, C.M., and VanderKooi, S.P., 2011, Spawning migration movements of Lost River and shortnose suckers in the Williamson and Sprague Rivers, Oregon, following the removal of Chiloquin Dam-2009 Annual Report: U.S. Geological Survey Open-File Report 2011-1147, 20 p. https://doi.org/10.3133/ofr20111147.

Evans, A.F., Hewitt, D.A., Payton, Q., Cramer, B.M., Collis, K., and Roby, D.D., 2016, Colonial waterbird predation on Lost River and shortnose suckers in the Upper Klamath Basin: North American Journal of Fisheries Management, v. 36, no. 6, p. 1254-1268, https://doi.org/10.1080/0 2755947.2016.1208123.

Hewitt, D.A., and Hayes, B.S., 2013, Monitoring of adult Lost River and shortnose suckers in Clear Lake Reservoir, California, 2008-2010: U.S. Geological Survey Open-File Report 2013-1301, 18 p. [Also available at https://doi.org/ 10.3133/ofr20131301.]

Hewitt, D.A., Janney, E.C., Hayes, B.S., and Harris, A.C., 2012, Demographics and run timing of adult Lost River (Deltistes luxatus) and shortnose (Chasmistes brevirostris) suckers in Upper Klamath Lake, Oregon, 2011: U.S. Geological Survey Open-File Report 2012-1193, 42 p., https://doi.org/10.3133/ofr20121193.

Hewitt, D.A., Janney, E.C., Hayes, B.S., and Harris, A.C., 2014, Demographics and run timing of adult Lost River (Deltistes luxatus) and shortnose (Chasmistes brevirostris) suckers in Upper Klamath Lake, Oregon, 2012: U.S. Geological Survey Open-File Report 2014-1186, 44 p. [Also available at https://dx.doi.org/10.3133/ofr20141186.]

Hewitt, D.A., Janney, E.C., Hayes, B.S., and Harris, A.C., 2017, Status and trends of adult Lost River (Deltistes luxatus) and shortnose (Chasmistes brevirostris) sucker populations in Upper Klamath Lake, Oregon, 2015: U.S. Geological Survey Open-File Report 2017-1059, 38 p. [Also available at https://doi.org/10.3133/ofr20171059.]

Hewitt, D.A., Janney, E.C., Hayes, B.S., and Harris, A.C., 2018, Status and trends of adult Lost River (Deltistes luxatus) and shortnose (Chasmistes brevirostris) sucker populations in Upper Klamath Lake, Oregon, 2017: U.S. Geological Survey Open-File Report 2018-1064, 31 p. [Also available at https://doi.org/10.3133/ofr20181064.]

Hewitt, D.A., Harris, A.C., Hayes, B.S., Kelsey, C.M., Janney, E.C., Perry, R.W., and Burdick, S.M., 2021, Dynamics of endangered sucker populations in Clear Lake Reservoir, California: U.S. Geological Survey Open-File Report 2021-1043, 59 p., https://doi.org/10.3133/ofr20211043.
Hightower, J.E., Jackson, J.R., and Pollock, K.H., 2001, Use of telemetry methods to estimate natural and fishing mortality of striped bass in Lake Gaston, North Carolina: Transactions of the American Fisheries Society, v. 130, no. 4, p. 557-567, https://doi.org/10.1577/15488659(2001)130<0557:UOTMTE>2.0.CO;2.

Hostetter, N.J., Evans, A.F., Roby, D.D., and Collis, K., 2012, Susceptibility of juvenile steelhead to avian predation-The influence of individual fish characteristics and river conditions: Transactions of the American Fisheries Society, v. 141, no. 6, p. 1586-1599, https://doi.org/10.1080/ 00028487.2012 .716011 .

Janney, E.C., Shively, R.S., Hayes, B.S., Barry, P.M., and Perkins, D., 2008, Demographic analysis of Lost River sucker and shortnose sucker populations in Upper Klamath Lake, Oregon: Transactions of the American Fisheries Society, v. 137, no. 6, p. 1812-1825, https://doi.org/ 10.1577/T06-235.1.

Liedtke, T.L., Beeman, J.W., and Gee, L.P., 2012, A standard operating procedure for the surgical implantation of transmitters in juvenile salmonids: U.S. Geological Survey Open-File Report 2012-1267, 50 p. https://doi.org/10.3133/ ofr20121267.

Lucas, M.C., Baras, E., Thom, T.J., Duncan, A., and Slavík, O., eds., 2001, Migration of freshwater fishes: Oxford, United Kingdom, Blackwell Science, 420 p., https://doi.org/ 10.1002/9780470999653.

Markle, D.F., Cavalluzzi, M.R., and Simon, D.C., 2005, Morphology and taxonomy of Klamath Basin suckers (Catostomidae): Western North American Naturalist, v. 65, p. 473-489.

Markle, D.F., and Cooperman, M.S., 2002. Relationships between Lost River and shortnose sucker biology and management of Upper Klamath Lake, chap. 5 of Braunworth, W.S., Welch, T., and Hathaway, R.L., eds., Water allocation in the Klamath Project, 2001: Corvallis, Oregon State University Extension, Special Report 1037, p. 93-117. [Also available at https://ir.library.oregonstate.edu/xmlui/ bitstream/handle/1957/7132/SR\%20no.\%201037.pdf.]

Martin, B.A., Hewitt, D.A., and Ellsworth, C.M., 2013, Effects of Chiloquin Dam on spawning distribution and larval emigration of Lost River, shortnose, and Klamath largescale suckers in the Williamson and Sprague Rivers, Oregon: U.S. Geological Survey Open-File Report 2013-1039, 28 p., https://doi.org/10.3133/ofr20131039. 
Martin, S.W., Long, J.A., and Pearsons, T.N., 1995, Comparison of survival, gonad development, and growth between rainbow trout with and without surgically implanted dummy radio transmitters: North American Journal of Fisheries Management, v. 15, no. 2, p. 494-498, https://doi.org/10.1577/1548-8675(1995)015<0494:COSGD $\mathrm{A}>2.3 . \mathrm{CO} ; 2$.

Modde, T., and Irving, D.B., 1998, Use of multiple spawning sites and seasonal movement by razorback suckers in the Middle Green River, Utah: North American Journal of Fisheries Management, v. 18, no. 2, p. 318-326, https://doi.org/10.1577/1548-8675(1998)018<0318:UOMS $\mathrm{SA}>2.0 . \mathrm{CO} ; 2$.

Moyle, P.B., 2002, Inland fishes of California: Berkeley, University of California Press, $502 \mathrm{p}$.

National Marine Fisheries Service and U.S. Fish and Wildlife Service (NMFS and USFWS), 2013, Biological opinions on the effects of proposed Klamath project operations from May 31, 2013, through March 31, 2023, on five federally listed threatened and endangered species: NMFS, Southwest Region and USFWS, Pacific Southwest Region, p. 1-607.

National Research Council (NRC), 2004, Endangered and threatened fishes in the Klamath River Basin-Causes of decline and strategies for recovery: Washington, D.C., The National Academies Press, $424 \mathrm{p}$.

O’Connor, J.P., Koehn, J.D., Nicol, S.J., O'Mahony, D.J., and McKenzie, J.A., 2009, Retention of radio tags in golden perch (Macquaria ambigua), silver perch (Bidyanus bidyanus) and carp (Cyprinus carpio): Marine and Freshwater Research, v. 60, no. 4, p. 334-340, https://doi.org/ 10.1071/MF08170.

Perkins, D.L., and Scoppettone, G.G., 1996, Spawning and migration of Lost River suckers (Deltistes luxatus) and shortnose suckers (Chasmistes brevirostris) in the Clear Lake drainage, Modoc County: California, National Biological Service, Reno Field Station, 58 p.

Perkins, D.L., Scoppettone, G.G., and Buettner, M., 2000, Reproductive biology and demographics of endangered Lost River and shortnose suckers in Upper Klamath Lake, Oregon: U.S. Geological Survey final report to the U.S. Bureau of Reclamation, Reno, Nevada, 40 p.
Piaskowski, R., 2003, Draft-Movements and habitat use of adult Lost River sucker and shortnose sucker in Link River and Keno impoundment Klamath River Basin: Oregon, U.S. Bureau of Reclamation, Klamath Basin Area Office, 68 p.

Prechtel, A.R., Coulter, A.A., Etchison, L., Jackson, P.R., and Goforth, R.R., 2018, Range estimates and habitat use of invasive Silver Carp (Hypophthalmichthys molitrix) -Evidence of sedentary and mobile individuals: Hydrobiologia, v. 805, no. 1, p. 203-218, https://doi.org/ 10.1007/s10750-017-3296-y.

Reyes-Tomassini, J.J., Moore, M., and Berejikian, B., 2016, AquaTracker Program Manual, version 2.40-National Oceanic and Atmospheric Administration: Washington, Manchester Research Station, 117 p.

Ross, M.J., and Kleiner, C.F., 1982, Shielded needle technique for surgically implanting radio-frequency transmitters in fish: Progressive Fish-Culturist, v. 44, no. 1, p. 41-43, https://doi.org/10.1577/1548-8659(1982)44[41:STFS IR]2.0.CO;2.

Scoppettone, G.G., Rissler, P.H., Fabes, M.C., and Withers, D., 2014, American white pelican predation on cui-ui in Pyramid Lake, Nevada: North American Journal of Fisheries Management, v. 34, no. 1, p. 57-67, https://doi.org/10.1080/02755947.2013.855278.

Scoppettone, G.G., and Vinyard, G., 1991, Life history and management of four endangered lacustrine suckers, in Minckley, W.L., and Deacon, J.E., eds., Battle against extinction-Native fish management in the American West: Tucson, Arizona, The University of Arizona Press, p. 359-377.

Smith, M.J., Von Bargen, J., Smith, C.T., Miller, M.R., Rasmussen, J., and Hewitt, D.A., 2020, Characterization of the genetic structure of four sucker species in the Klamath River Basin-Final report-Report to the Bureau of Reclamation from Abernathy Fish Technology Center: U.S. Fish and Wildlife Service, $32 \mathrm{p}$.

Thurow, R.F., 2016, Life histories of potamodromous fishes, chap. 4 of Morais, P., and Daverat, F., eds., An introduction to fish migration: Boca Raton, Florida, CRC Press, p. $29-54$.

U.S. Fish and Wildlife Service (USFWS), 1988, Endangered and threatened wildlife and plants-Determination of endangered status for the shortnose sucker and Lost River sucker: Federal Register, v. 53, p. 27130-27134. 
U.S. Fish and Wildlife Service (USFWS), 2001, Biological/ conference opinion regarding the effects of operation of the Bureau of Reclamation's Klamath Project on the endangered Lost River sucker (Deltistes luxatus), endangered shortnose sucker (Chasmistes brevirostris), threatened bald eagle (Haliaeetus leucocephalus), and proposed critical habitat for the Lost River/shortnose suckers: U.S. Fish and Wildlife Service, Klamath Falls Fish and Wildlife Office, Oregon, 188 p.

U.S. Fish and Wildlife Service (USFWS), 2012, Designation of critical habitat for Lost River sucker and shortnose sucker-Proposed Rule: Federal Register, v. 77, p. $73740-73768$.
U.S. Fish and Wildlife Service (USFWS), 2015, Species report for the Modoc sucker (Catostomus microps): U.S. Fish and Wildlife Service, Klamath Falls Fish and Wildlife Office, Oregon, $39 \mathrm{p}$.

Walsh, M.G., Bjorgo, K.A., and Isely, J.J., 2000, Effects of implantation method and temperature on mortality and loss of simulated transmitters in hybrid striped bass: Transactions of the American Fisheries Society, v. 129 , no. 2, p. 539-544, https://doi.org/10.1577/15488659(2000)129<0539:EOIMAT>2.0.CO;2.

Wickham, H., 2016, ggplot2-Elegant graphics for data analysis: New York, Springer-Verlag, 224 p. 
Publishing support provided by the U.S. Geological Survey Science Publishing Network, Tacoma Publishing Service Center

For more information concerning the research in this report, contact the

Director, Western Fisheries Research Center

U.S. Geological Survey

6505 NE 65th Street

Seattle, Washington 98115-5016

https://www.usgs.gov/centers/wfrc 
